\title{
Keholliset ja materiaaliset sananselityssekvenssit aikuisten S2-lukutaito-opiskelijoiden luokkahuonevuorovaikutuksessa
}

\author{
Laura Eilola
}

\section{Johdanto}

Eri tavoin lukemiseen ja kirjoittamiseen tukea tarvitsevien suomen kielen opiskelijoiden määrä kasvaa koko ajan, ja maahanmuuttajaväestön määrän lisääntyessä luku- ja kirjoitustaidon koulutuksen opiskelija-aines on monipuolistunut (Testipiste 2016; Opetus- ja kulttuuriministeriö 2017: 16-17). Tutkimusta tämän viiteryhmän kielitaidon kehittymisestä on kuitenkin vasta hyvin vähän (ks. kuitenkin Tammelin-Laine 2014a). Näin ollen myöskään aikuisten luku- ja kirjoitustaidon opiskelijoiden vuorovaikutuskompetenssin kehittymisestä ei juuri ole tutkimustietoa. Vuorovaikutuskompetenssilla (engl. interactional competence, Hall \& Pekarek Doelher 2011: 2-3) tarkoitetaan kykyä toimia tarkoituksenmukaisesti erilaisissa vuorovaikutustilanteissa. Aiemman tutkimuksen perusteella silti tiedetään, että luku- ja kirjoitustaidon ollessa heikko kielenoppiminen perustuu paljon kuulon varaan ja että oman äidinkielen luku- ja kirjoitustaidolla on yhteys suullisen kielitaidon kehittymiseen muilla kielillä (Tammelin-Laine 2014a: 18-19; Tarone, Bigelow \& Hansen 2009: 19, 26, 116).

Tässä artikkelissa pyrin multimodaalista keskustelunanalyysia (Mondada 2014a, 2016, 2018) hyödyntäen osoittamaan, miten sanelun jälkeiset sekvenssit rakentuvat aikuisten maahanmuuttajien luku- ja kirjoitustaidon koulutuksen luokkahuonevuorovaikutuksessa. Varsinaisista aikuisten lukutaitoluokista ei ole aiemmin julkaistu multimodaalista keskustelunanalyyttista tutkimusta. Keskityn sanelun jälkeiseen toimintaan, koska sanelu on yleinen toimintotyyppi niin aikuisten luku- ja kirjoitustaidon koulutuksessa yleisesti (Tammelin-Laine 2014b: 54) kuin omassa aineistossanikin. Sanelun jälkeen vuorovaikutuksessa rakentuu paikka sananselityksille. Selitykset ovat sekventiaalisesti jäsentyviä ja vuorovaikutteisesti syntyviä aktiviteetteja (Heller 2016: 254), joissa rakennetaan tietoa kommunikaatioon liittyvän ongelman ratkaisemiseksi (Erath, Prediger, Quasthoff \& Heller 2018: 164). Selityssekvenssin alkaminen edellyttää, että vähintään kahden tilanteen osallistujan välillä vallitsee joko tiedollinen tai ymmärrykseen liittyvä epäsymmetria (Stivers, Mondada \& Steensig 2011). 
Ideaalinen lopputulos selityssekvenssin päättyessä puolestaan on, että ennen sekvenssin alkamista osallistujien välillä ollut epäsymmetria tasapainottuu (Merke 2016: 13). Luokkahuonekontekstissa opettajat kuitenkin usein pyytävät oppijoita selittämään myös asioita, jotka he itse tuntevat hyvin. Tällöin toiminta ei välttämättä perustu tiedolliseen eikä ymmärrykselliseen epäsymmetriaan vaan sillä on pedagoginen funktio: se antaa opiskelijoille mahdollisuuden osoittaa ymmärtämistä ja opettajalle tilaisuuden arvioida, mitä nämä osaavat ja tietävät. (Dalton-Puffer 2007: 141-142.)

Vaikka erilaisten multimodaalisten resurssien merkitys luokkahuoneen (sanan-) selityksissä onkin tunnistettu jo monissa tutkimuksissa esimerkiksi eleiden ja taulun hyödyntämisenä (ks. van Compernolle \& Smotrova 2017; Lazaraton 2004; Majlesi 2015; Mortensen 2011; Morton 2015; Tai \& Khabbazbashi 2019a; Waring, Creider \& Box 2013), kielellinen toiminta on kuitenkin näiden tutkimusten mukaan ensisijainen selitystapa verrattuna muihin modaliteetteihin (ks. kuitenkin Tai \& Khabbazbashi 2019b). Eleiden on opetus- ja ohjaustilanteissa muun muassa havaittu elaboroivan selittävää puhetta, esiintyvän yhdessä puheen kanssa sellaisissa käyttökonteksteissa, joissa ne ovat sidoksissa välittömään toimintaympäristöönsä, ja olevan osa selittävää verbaalista esitystä (Belhiah 2013; Waring ym. 2013; Morton 2015).

Useimmiten sananselityksiä tai käsitteen määrittelyä tarkastelevien tutkimusten fokuksessa on ollut opettajan selitystoiminta, kun taas vähemmän huomiota on saanut se, miten oppijat selittävät asioiden merkityksiä luokkahuoneessa paitsi verbaalisesti myös esimerkiksi esittäviä eleitä hyödyntäen tai jotakin objektia osoittamalla (ks. kuitenkin Heller 2016; Mortensen 2011; Tai 2018). Toisaalta oleellista on huomioida, että opettaja ja oppijat tuottavat usein selityksiä ja määrittelyjä luokassa nimenomaan yhdessä (Koole 2010; Kääntä, Kasper \& Piirainen-Marsh 2018; Merke 2016; Mortensen 2011; Morton 2015; Sert 2015: 104-106). Oppijoiden näkökulman huomioimista ja siihen fokusoituvaa tutkimustietoa tarvitaan, sillä oppijan oman osallistumisen uskotaan olevan tärkeää, jopa välttämätöntä, toisen kielen oppimiselle. Edellyttämällä tai rohkaisemalla opiskelijoita osallistumaan aktiivisesti luokkahuoneen toimintaan voidaan vahvistaa oppijoiden osallisuutta omissa oppimisprosesseissaan. Osallistuminen puolestaan luo mahdollisuuksia kielen oppimiselle. (Mortensen 2008: 3; Sert 2017; ks. myös Sahlström 1999: 181.)

Tämän artikkelin tavoitteena on analysoida sanelun jälkeisten sananselityssekvenssien rakentumista aikuisten luku- ja kirjoitustaidon koulutuksen luokkahuoneen vuorovaikutuksessa ja sitä, millainen rooli erilaisilla kielellisillä, kehollisilla ja materiaalisilla resursseilla on näissä toimintojaksoissa. Kiinnitän huomiota erityisesti S2-lukutaito-opiskelijoiden ${ }^{1}$ keholliseen toimintaan ja läsnä olevien materiaalisten resurssien hyödyntämiseen sekä siihen, miten ne kytkeytyvät tilanteissa käytettyyn kieleen. Rajaan huomioni opiskelijoiden tuottamiin sananselityksiin, jotka saavat alkunsa opettajan aloitteesta. ${ }^{2}$

1. Suni, Tammelin-Laine ja Vertainen (toim. 2018: 3) ovat EU-Speak-3-hankkeen raportissaan viitanneet jokseenkin vastaavan kielenoppijaryhmän jäseniin nimikkeellä S2-lukutaito-oppija. Koska tämän tutkimuksen aineisto on kuitenkin kerätty virallisesta kielikoulutuksesta, käytän tutkimukseni osallistujista termiä (S2-lukutaito-)opiskelija tai (suomen kielen ja lukutaidon) opiskelija.

2. Kiitän väitöskirjani ohjaajia Niina Liljaa ja Arja Piirainen-Marshia sekä tämän artikkelin anonyyme- 


\section{Monikielisen luokkahuoneen vuorovaikutustilanteet}

Kun opiskelija ei osaa opetuskieltä eikä hänellä ole yhteistä kieltä muiden samassa ryhmässä opiskelevien kanssa, erilaisten kehollisten ja materiaalisten resurssien merkitys on niin yhteisen ymmärryksen rakentamisen kuin oppimisenkin näkökulmasta erityisen suuri. Lähtökohtani tässä artikkelissa on, että kielenoppiminen on tilanteista vuorovaikutustoimintaa (Firth \& Wagner 1997; Markee \& Kasper 2004), joka on yhteydessä tilanteen kannalta keskeisiin kielellisiin, kehollisiin ja materiaalisiin resursseihin (ks. esim. Hall, Hellermann \& Pekarek Doehler toim. 2011; Pekarek Doehler 2010). Aikuinen, jolla on vain vähän kokemusta formaalista koulutuksesta, kohtaa luokkahuoneeseen astuessaan aivan uuden toimintaympäristön ja uudet toimintakäytänteet (Hellermann \& Harris 2015: 70-71). Luokkahuoneen toimintaan ja yhteisöön sosiaalistutaan osana oppimisprosessia, ja myös tämä on vuorovaikutuskompetenssin kehittymistä (Hellermann 2018; Mehan 1979: 126-171).

\subsection{Multimodaaliset sananselitykset luokkahuoneen vuorovaikutustilanteissa}

Sanan merkityksestä voidaan tuottaa tietoa paitsi kääntämällä se toiselle yhteiselle kielelle myös kohdekielisesti esimerkiksi esittämällä määritelmä, parafraasi, kiertoilmaus tai selostus, luomalla sanalle konteksti tai käyttämällä esimerkiksi synonyymia, antonyymia tai muita ilmauksia, jotka ovat semanttisesti symmetrisessä yhteydessä selitettävään sanaan (Zhao \& Macaro 2016: 76). Sanaston merkityksen läpikäyminen on osa L2-oppitunnin kulkua. Osallistumalla selittämiseen opiskelijat voivat vaikuttaa omiin oppimismahdollisuuksiinsa, ja toisaalta opiskelijoiden toiminta antaa opettajalle tietoa siitä, mitä nämä osaavat (Mortensen 2011: 157). Aiempi monikielisen luokkahuoneen (sanan)selityksiä tarkasteleva tutkimus on koskenut lähinnä spontaanisti luokkahuoneen vuorovaikutuksessa syntyviä selityksiä (Lazaraton 2004; Mortensen 2011; Waring ym. 2013; Merke 2016; Tai 2018, ks. kuitenkin Morton 2015).

Multimodaalisia keinoja ovat esimerkiksi puhe, kehon asennot ja liikkeet, eleet, katse, prosodia ja ilmeet sekä materiaalisen ympäristön, esimerkiksi esineiden, tilan, paikan ja liikkeen, hyödyntäminen. Multimodaaliset keinot ovat tärkeitä yhteisen ymmärryksen rakentumisessa, ja niiden merkitykset varioivat tilanteisesti. (Kääntä \& Haddington 2011: 11, 34; Mondada 2014a: 138-140; Streeck, Goodwin \& LeBaron 2011: 1-5.) Sananselitysten multimodaalisuudesta ja niitä monin tavoin muistuttavista käsitteen määrittelyistä on olemassa tutkimustietoa niin toisen kielen oppimisen (esim. Belhiah 2013; Majlesi 2015; Mortensen 2011; Tai \& Khabbazbashi 2019a, 2019b; Waring ym. 2013) kuin esimerkiksi CLIL-opetuksen (Kääntä 2016; Kääntä ym. 2018; Morton 2015) ja matematiikan oppimisen (esim. Erath ym. 2018; Heller 2016; Koole 2010) näkökulmistakin. Aiemman tutkimuksen perusteella monikielisen luokkahuoneen sananselityssekvensseille on tyypillistä, että opettaja tuo keskeisen sanastollisen seikan huomion kohteeksi verbaalisesti tai osoittamalla sitä taululla, sekä se, että opettaja se-

ja arvioijia huolellisesta paneutumisesta tekstiini kirjoitusprosessin eri vaiheissa. Lämmin kiitos myös Emil Aaltosen Säätiölle tämän tutkimuksen rahoittamisesta. 
littää sanaa tai käsitettä käyttämällä kohdekielisiä synonyymejä tai kääntämällä selitettävän sanan muille kielille ja pyrkii näin myös siihen, että oppijat osoittaisivat ymmärtävänsä tai tietävänsä sanan merkityksen. Yleensä sanalle luodaan myös jonkinlainen käyttökonteksti, tyypillisimmin joko kuvitteellinen tai todellinen esimerkkilause. Usein sen jälkeen, kun opettaja on fokusoinut sanaan, opiskelijat toistavat sen. Kielellisten resurssien lisäksi (liitu-/tussi-)taulu on keskeinen materiaalinen resurssi luokkahuoneen sananselitystilanteiden alkamisessa, sillä yleensä opettaja kirjoittaa selitettävän sanan taululle tai alleviivaa sen. (Mortensen 2011; Morton 2015; Tai \& Khabbazbashi 2019b; Waring ym. 2013.) Tain ja Brandtin (2018: 19) mukaan keholliset resurssit näyttäisivät auttavan etenkin toisen kielen alkeisoppijoita sanaston ja fraasien oppimisessa, kun yhteiset kielelliset resurssit ovat vähäiset.

Eletutkimuksen pioneeri, David McNeill (1992: 37), on määritellyt eleet spontaaneiksi kämmenillä ja käsivarsilla tehtäviksi liikkeiksi, jotka täydentävät puhetta. Sittemmin tätä määritelmää on täydennetty huomauttamalla, että eleitä voidaan tuottaa myös esimerkiksi pään ja jopa jalkojen liikkeiden avulla (ks. esim. Kendon 2004: 101102; Mondada 2014a: 142). McNeillin eletutkimuksessa on uraauurtavaa se, että hän on painottanut kielen ja eleiden tiivistä suhdetta: eleet kytkeytyvät kiinteästi puhuttuun kieleen ajoitukseltaan, merkitykseltään ja funktioltaan. Lisäksi hän on jakanut eleet neljään eri kategoriaan: ikonisiin eli esittäviin (iconics), deiktisiin eli osoittaviin (deictics), metaforisiin (metaphorics) eleisiin sekä syke-eleisiin (beats). (McNeill 1992: 1, 12-18.) Tämän artikkelin kannalta oleellisia ovat etenkin ikoniset eleet, jotka ovat hyvin kiinteässä suhteessa puheeseen ja havainnollistavat puheen semanttista sisältöä.

Aiemmat pitkittäistutkimukset kakkoskielisen sanaston oppimisen näkökulmasta luokkahuoneen vuorovaikutustilanteissa osoittavat, että eleillä on tärkeä funktio yhteisymmärryksen saavuttamisessa. Oleellista on myös, että ele on itsessään semioottinen yhteisen ymmärryksen rakentamisen resurssi muiden resurssien joukossa eikä vain väline, jolla kompensoidaan vuorovaikutustilanteissa kielitaidon puutteita tai jota käytetään pelkästään muiden semioottisten resurssien, kuten sanojen, oppimiseen. (Eskildsen \& Wagner 2013; 2015: 290-292.) Opettajat voivat paitsi havainnollistaa sanoja myös sijoittaa niitä eleiden avulla tiettyihin tilanteisiin konteksteihin muuten verbaalisissa sananselityksissään (van Compernolle \& Smortrova 2017; Sert 2017). Ohjauskeskustelukontekstissa eleitä on havaittu hyödynnettävän merkityksellisesti käsitteen määrittelyissä pääasiassa kolmella tavalla: vahvistamaan verbaalisten lausumien merkitystä, selventämään sanastollisia kohtia ja luomaan koheesiota vuorojen välille (ks. Belhiah 2013).

Vasta aivan viime aikoina (sanan)selityksiä koskevien tutkimusten ${ }^{3}$ yhteydessä on esitelty termi kehollinen selittäminen (embodied explanation). Sert (2017: 15) määrittelee sen selitykseksi, joka sisältää eksplisiittisesti visuaalista toimintaa, kuten käsieleiden käyttöä. Kehollisen selittämisen lähikäsitteenä voidaan pitää puolestaan käsitettä kehollinen esittäminen (embodied enactment, Tai \& Brandt 2018: 2). Tai ja Brandt (mp.) määrittelevät sen hypoteettisten skenaarioiden verbaaliseksi ja fyysiseksi esittämiseksi, jonka tarkoituksena on tuottaa selvityspyyntöjä tai selityksiä ja näin rakentaa silta

3. Kyse on nimenomaan luokkahuonekontekstia koskevista tutkimuksista. 
luokkahuonediskurssista ja -vuorovaikutuksesta kieliluokan ulkopuolelle. Kehollisessa esittämisessä luodaan fyysisesti tilanteinen konteksti, joka auttaa opiskelijoita ymmärtämään, miten kohdekieltä voidaan käyttää spesifeissä tilanteissa (mas. 19; ks. esittämisestä myös Clark 2016). Kehollisen selittämisen ja esittämisen lisäksi viime vuosina on alettu ohjauskontekstissa tutkia yhä enemmän myös kehollisia demonstraatioita, joissa ohjaaja näyttää kehoaan hyödyntäen, miten ohjattavan tulisi seuraavaksi toimia (Evans \& Reynolds 2016; Keevallik 2014; Lindwall \& Ekström 2012; Nishizaka 2017; Råman \& Haddington 2018). Koska tässä artikkelissa fokusoin oppijoiden sananselityksiin, en käytä opetus- ja ohjaustilanteissa kehollisen demonstraation käsitettä vaan operoin käsitteellä kehollinen esittäminen viitatessani siihen keholliseen toimintaan, jolla opiskelijat ja opettaja yhdessä rakentavat sananselityksiä: osallistujat eivät yleensä pyri ohjaamaan toistensa kehollista toimintaa, vaan tyypillisesti he esittävät hypoteettisia tilanteita, joihin selitettävä sana tavalla tai toisella liittyy. Kehollinen esittäminen tulee hyvin lähelle myös Mondadan käsitettä complex multimodal Gestalt, joka tarkoittaa vuorovaikutustilanteessa samanaikaisesti käytettävien multimodaalisten resurssien muodostamaa kokonaisuutta, jonka perustana on vuorovaikutuksen jäsentyneisyys (Mondada 2014a: 140-142; 2014b: 357-358). Selvyyden vuoksi käytän kuitenkin Gestaltin sijaan tässä artikkelissa kehollisen esittämisen käsitettä. Multimodaalisuutta luku- ja kirjoitustaidon opiskelijoiden näkökulmasta tarkastelevaa tutkimusta on vähän, mutta tähänastisen tutkimuksen perusteella tiedetään, että esimerkiksi deiktisten eleiden (oppimateriaalin osoittamisen), pantomiimin ja vertaisten kanssa yhteisen ensikielen käyttämisestä on hyötyä yhteisen ymmärryksen saavuttamisessa (Hellermann 2018: 45-47).

Luokkahuone on tilana perinteisesti järjestetty niin, että opettaja seisoo luokan etuosassa ja pulpetit ovat riveissä niin, että jokaisen oppijan kasvot ovat opettajaan päin. Tästä perinteestä on kuitenkin jo pidemmän aikaa ollut myös poikkeuksia. (Tainio 2007: 35.) Sananselitysten näkökulmasta luokkahuoneen tilajärjestelyt vaikuttavat ohjaavan oppijoiden multimodaalisten resurssien käyttöä. Vaikuttaisi siltä, että mitä lähempänä selittäjää selityksen kannalta potentiaalisesti merkitykselliset objektit ovat fyysisesti, sitä todennäköisemmin selittäjä myös käyttää niitä resurssina verbaalisessa selityksessään: esimerkiksi omassa kädessä olevaa objektia hyödyntämällä selityksiä voidaan ilmaista paitsi kehollisesti myös verbaalisesti seikkaperäisemmin ja laajemmin (ks. Heller 2016: 268-270). Näin ollen oppijoiden mahdollisuudet koordinoida multimodaalisia resursseja luokkahuoneessa voivat vaikuttaa osallistumiseen sananselitysaktiviteetissa.

Selitettävän sanan abstraktiotasolla ja semantiikalla voi olla merkitystä sille, kuinka sana selitetään. Waring ym. (2013) jakavat opettajan sananselitykset analyyttisiin (analytic) ja animoituihin (animated) sen perusteella, millaisia resursseja niissä käytetään. Analyyttiset selitykset rakennetaan kielellisin keinoin. Niissä voidaan hyödyntää esimerkiksi sanan rakenteellisia tai semanttisia ominaisuuksia, aiemmin luettua tekstiä tai esimerkkilausetta. Analyyttinen lähestymistapa sopii varsinkin abstraktien substantiivien ja tietynlaisten, hankalasti visualisoitavien, verbien selittämiseen. Animoidut selitykset taas ovat sosiaalisempia, tilanteisempia ja moninaisempia, ja niissä käytetään selittävän puheen lisäksi monia muitakin multimodaalisia resursseja. Näin ne myös sitouttavat kielenoppijoita enemmän luokkahuoneen selitystoimintaan kuin 
analyyttiset selitystilanteet. Helposti visualisoitavat (eli usein melko konkreettiset) sanat sopivat hyvin animoituihin selityksiin. Animoidut selitykset voidaan jakaa edelleen kolmeen erilaiseen tyyppiin: puhe ja ele, puhe yhdessä välittömään toimintaympäristöönsä sidosteisen eleen kanssa (ks. yleisemmin käsitteestä environmentally coupled gesture, Goodwin 2007a: 198-199; 2007b: 55-56) sekä puhe osana laajempaa esitettävää kohtausta (scene enactment). Animoidut selitykset voivat siis ilmentää huomattavan monimutkaisiakin asetelmia. (Waring ym. 2013.) Mortonin (2015: 267) mukaan samassa sekvenssissä voidaan kuitenkin käyttää myös analyyttisen ja animoidun selityksen kombinaatiota.

Selityksiin voi liittyä ymmärtämisen osoittamista ilmaisevia aktiviteetteja (Koole 2010: 208). Ymmärtämisen osoituksella tai demonstraatiolla tarkoitetaan ymmärtämisen ilmaisemista niin, että osallistuja ei pelkästään väitä ymmärtävänsä vaan tekee jonkinlaista analyysia edellisen osallistujan vuorosta ja ilmentää sen seuraavassa lausumassaan (Sacks 1992: 253; Koole 2010: 192). Spontaanisti luokkahuoneen vuorovaikutuksessa syntyviä, yhdessä rakennettuja sanaston selityksiä CLIL-opetuksessa (Content and Language Integrated Learning) tarkastellut Morton (2015: 267) argumentoi, että sanaston selitykset rakentuvat ennen kaikkea ymmärtämisen (understanding display sequence) ja tietämisen osoitussekvenssien (knowledge display sequence) ketjutuksen varaan. Hänen mukaansa pelkkä ymmärtämisen osoitus ei riitä päättämään selityssekvenssiä ja saa osallistujia palaamaan sisältöaktiviteettiin. (Mp.) Näin hän määrittää myös ymmärtämisen osoituksen ja sananselityksen välistä rajapintaa luokkahuoneen vuorovaikutuksessa: sananselitykset koostuvat ymmärtämisen osoituksista, mutta ymmärtämisen osoituksia ei itsessään yleensä kohdella sananselityksinä. Morton (mas. 267-268) on havainnut myös, että CLIL-opetuksessa selitettävälle sanastolle luodaan toisen kielen oppitunteja todennäköisemmin konteksti nimenomaan sisältöaineen puitteissa niin, että se kiinnittyy meneillään olevaan pedagogiseen aktiviteettiin. Vaikka katsontakanta sanan merkitykseen jäisikin näin kapeaksi, selitys nojautuu kuitenkin etupäässä sisältöaineen suomaan kontekstiin (mp.). CLIL-luokkia ja aikuisten lukuja kirjoitustaidon koulutuksen luokkia voidaan pitää akateemisten taitojen näkökulmasta eräällä lailla ääripäinä. Näiden koulutusten eroista huolimatta nojaudun aiempaan CLIL- ja matematiikan tunteja koskevaan tutkimustietoon ymmärtämisen osoituksista osana selitysaktiviteettejä ja -sekvenssejä, sillä aikuisten luku- ja kirjoitustaidon koulutuksen luokkahuonevuorovaikutuksen näkökulmasta vastaavaa tutkimusta ei ole tehty. Oma tutkimukseni osaltaan paikkaa tätä tutkimusaukkoa.

\subsection{Sanelu aikuisten luku- ja kirjoitustaidon koulutuksen pedagogisena aktiviteettina}

Tässä artikkelissa tarkasteltavat sananselitykset ovat hyvin todennäköisesti osa opettajan agendaa, sillä niitä edeltää aikuisten luku- ja kirjoitustaidon koulutuksessa tyypillinen ja aineistossani toistuva toimintatyyppi, sanelukirjoitus, jonka jälkeen sanelun sanat kirjoitetaan tussitaululle kaikkien nähtäväksi. Kun sanat ovat taululla, siirrytään yleensä varsinaisesta sanelutilanteesta ja sanojen kirjoittamisesta niiden merkitysten selittämiseen. Aineistossa sanelukirjoitus on siis osa laajempaa pedagogista aktiviteettia, jota nimitän saneluaktiviteetiksi. 
Sanelukirjoitus on yleinen tehtävätyyppi aikuisten luku- ja kirjoitustaidon koulutuksessa (ks. Tammelin-Laine 2014b: 54). Tähän on myös vahvat perusteet. Puhuttu kieli on primaaria kielellistä toimintaa suhteessa kirjoitettuun kieleen, ja samoja kognitiivisia perustaitoja käytetään niin puhutun kuin kirjoitetunkin kielen oppimisessa (Ahvenainen \& Holopainen 2014: 12-13). Sanelukirjoituksessa opetellaan yhdistämään tietyt puhutussa kielessä kuullut fonologiset hahmot tiettyihin visuaalisiin hahmoihin, eli siinä käydään läpi analyysiprosessi, jossa puhutusta tekstistä tehdään kirjoitus (mts. 31).

Puhutussa ja kirjoitetussa kielessä on kuitenkin erilainen sanasto ja rakenne, ja niitä käytetään eri aistikanavien kautta, joten molempien kielimuotojen oppimiseen tarvitaan opetusta ja harjoitusta (Tammelin-Laine 2014a: 41). Aikuisilla luku- ja kirjoitustaidon oppijoilla erityisesti kirjain-äännevastaavuuden hahmottaminen harjaantuu sanelukirjoituksessa, ja varsinkin suomen kielessä, jossa on vahva kirjainäännevastaavuus, suullinen kielitaito tukee kirjallisten taitojen kehittymistä ja päinvastoin (Tammelin-Laine 2014a: 65-66; 2014b: 67).

Suullisessa vuorovaikutuksessa tapahtuvan toiston merkitys on erityisen suuri heikosti lukevien ja kirjoittavien aikuisten luokkahuonevuorovaikutuksessa: kun sanasto ei toistu lukemisen kautta, sen tulee kertaantua enemmän suullisesti (ks. Tammelin-Laine 2014a: 19, 28; Tarone ym. 2009: 109-110). Lisäksi Tammelin-Laine (mts. 67) huomauttaa, että jos sanoja ei tiedä, niitä ei voi kirjoittaa. Tutkimukseni tuokin uutta tietoa siitä, miten S2-lukutaito-opiskelijat oppivat sanastoa sananselitysten avulla.

\section{Aineisto ja analyysimenetelmät}

Tämän tutkimuksen aineisto on kerätty etnografisella otteella videoiden luku- ja kirjoitustaidon ryhmien vuorovaikutusta luokkahuoneessa ja sen ulkopuolella erilaisissa arjen vuorovaikutustilanteissa. Olen havainnoinut osallistuvasti ja useilla videokameroilla ja äänentallentimilla toimintaa kooten yhteensä noin 123 tunnin aineiston kolmesta eri ryhmästä kahdessa eri oppilaitoksessa. Aineiston ryhmillä oli yhteensä viisi eri opettajaa. Tämän artikkelin ydinaineiston muodostaa 68 tuntia luokkahuonevuorovaikutustilanteita.

Ennen aineistonkeruun aloittamista oppilaitoksilta ja ryhmien opettajilta pyydettiin kirjallisesti ja opiskelijoilta suullisesti luvat aineistonkeruuseen ja suostumus osallistua tutkimukseen. Osallistumisen kerrottiin olevan vapaaehtoista. Tutkimuksen idea ja tavoitteet selitettiin opiskelijoille selkosuomeksi ja osittain tulkkeja käyttäen: ensimmäisen ryhmän farsia sujuvasti osaava opettaja tulkkasi tarpeen mukaan tutkimusidean ryhmän farsinkielisille, ja kahdessa viimeisimmässä ryhmässä paikalle tilattiin opiskelijoiden äidinkielten tai osaamien kielten tulkit (ryhmässä 2 arabia ja farsi; ryhmässä 3 arabia, dari ja somali). Tämän lisäksi tutkimuksen tarkoitusta selitettiin useita kertoja uudelleen ja tarvittaessa lupia pyydettiin prosessin aikana uudestaan. Suostumukset dokumentoitiin videoimalla tai äänittämällä sen mukaan, minkälaista tutkittavien toimintaa oli lupa tallentaa. Yhdessä ryhmässä kaikki antoivat luvan videoimiseen, mutta kahdessa vain osalta opiskelijoista oli suostumus kuvaamiseen. Kaikkien ryhmien jokaisen opiskelijan toimintaa oli kuitenkin lupa äänittää. Näin ollen kamerat 
kohdennettiin niin, että kuvattavana olemisesta kieltäytyneet jäivät kameroiden kuvakulmien ulkopuolelle. Jos he liikkuivat luokassa, kameroiden linssit peitettiin tai suunnattiin uudelleen täksi ajaksi.

Tässä artikkelissa tarkastelen sanelun jälkeisiä toimintojaksoja, jotka ovat yleensä sananselityksiä. Yleensä saneluiden sanat ovat joko konkreettisia substantiiveja tai verbejä. Huomioni kohteena olevat sananselitykset eivät ole spontaaneja ${ }^{4}$, vaan ne ovat hyvinkin odotuksenmukaisia ja osa opettajan pedagogista tavoitetta. Aineistossa on yhteensä 24 videoitua saneluaktiviteettia ja näiden lisäksi kaksi numerosanelua ${ }^{5}$. Kussakin sanelussa oli saneltavia sanoja 7-27, tyypillisimmin yksitoista sanaa.

Aineisto on analysoitu multimodaalista keskustelunanalyysia (Mondada 2014a, 2016, 2018) hyödyntäen ja Mondadan (2020) kehittämää multimodaalista litterointijärjestelmää soveltaen (ks. myös Harjunpää, Mondada \& Svinhufvud 2020). Litteraatteja ei ole kuitenkaan käännetty kaikista osallistujien käyttämistä kielistä suomeksi, sillä kaikki luokassa käytettävät kielet eivät ole ymmärrettävissä myöskään kaikille osallistujille. Analyysin esimerkeissä 2 ja 3 havainnollistan myös videoista otetuilla, pseudonymisoiduilla kuvakaappauksilla erilaisten multimodaalisten resurssien käyttöä sananselityksissä.

\section{Sanelukirjoituksen jälkeinen toiminta ja sananselitysten rakentuminen}

Keskityn analyysissa sekvensseihin, jotka toteutuvat aikuisten luku- ja kirjoitustaidon koulutukselle yleisen tehtävätyypin, sanelukirjoituksen, jälkeen. Ensin alaluvussa 4.1 näytän esimerkissä 1, miten paikka sananselitykselle rakentuu, minkä jälkeen myöhemmin alaluvuissa kuvaan, miten selityssekvenssit aineistossa tyypilliset etenevät substantiivien (luku 4.2) ja verbien (luku 4.3) osalta. Aineiston saneluiden jälkeisissä sananselityssekvensseissä on jonkin verran variaatiota, mutta tietynlainen toistuva rakenne on silti yleinen. Tyypillisesti selitykset alkavat niin, että yksi tai useampi opiskelija toistaa sanan verbaalisesti. Tämän jälkeen yleensä yksi sanan toistaneista opiskelijoista tekee esittävän eleen tai kehollisen esityksen, jota seuraa aluksi hyvin samantyyppinen ja sittemmin varioivampi muidenkin osallistujien kehollinen toiminta. Vasta tämän jälkeen opiskelijat suuntautuvat, tyypillisesti opettajan aloitteesta, sanan semantiikan tarkasteluun, kun opettaja on ensin hyväksynyt tai vahvistanut yhdessä rakennetun selityksen. On kiinnostavaa, että sekä substantiivien että verbien selittämisessä kuvataan yleensä nimenomaan toimintaa. Koska kehollisen toiminnan merkitys on aineistossani ilmeinen, fokusoin selitysten analyysissa siihen. Olen valinnut

\footnotetext{
4. Aineistossani on kuitenkin myös toimintojaksoja, joissa sanelukirjoituksen aikana syntyy spontaaneja sananselityksiä. Yleensä tällaiset tilanteet syntyvät niin, että joku opiskelijoista kysyy saneltavana olevan sanan merkitystä ja opettaja vastaa selittämällä, minkä jälkeen opiskelijat joko toistavat sanaa tai esittävät tarkentavia kysymyksiä.

5. Numerosaneluiden jälkeinen toiminta ei ole mukana analyysissa, sillä niissä merkitysten selventäminen ei aiheuttanut selityssekvenssejä, vaan kukin opiskelija sanoi yhden luvun vuorollaan ääneen ja sitten opettaja kirjoitti luvut kaikkien nähtäviksi joko dokumenttikameran kautta näkyvälle paperille tai tussitaululle.
} 
aineistosta kaksi jaksoa esimerkeiksi, koska ne havainnollistavat tyypillisiä tapoja selittää konkreettisia substantiiveja (luku 4.2, esim. 2) ja verbejä (luku 4.3, esim. 3) ja niissä molemmissa näkyy monella tavalla opiskelijoiden orientoituminen sanaston oppimiseen.

\subsection{Otollisen paikan rakentuminen sananselitykselle}

Aluksi opettaja tyypillisesti ilmoittaa, että on aika käydä sanojen merkitykset läpi. Sitten hän ympyröi yhden taululle kirjoitetun sanan kerrallaan, toistaa sen verbaalisesti ja kääntyy luokkaa kohti. Tässä tilanteessa luodaan mahdollisuus sananselityksen syntymiselle. Opettaja rakentaa vuorollaan kysymyksen, johon odotuksenmukainen vuoro on selitys. Esimerkistä 1 näkyy, kuinka opettaja (OPE) osoittaa siirtymistä pedagogisen aktiviteetin seuraavaan vaiheeseen eli sanelun sanojen merkitysten läpikäyntiin. Samalla hän luo kyseisessä sanelutilanteessa ensimmäisen paikan, jossa opiskelijat voivat tuottaa sananselityksen.

(1) Katsotaan mitä ne sanat tarkoittaa

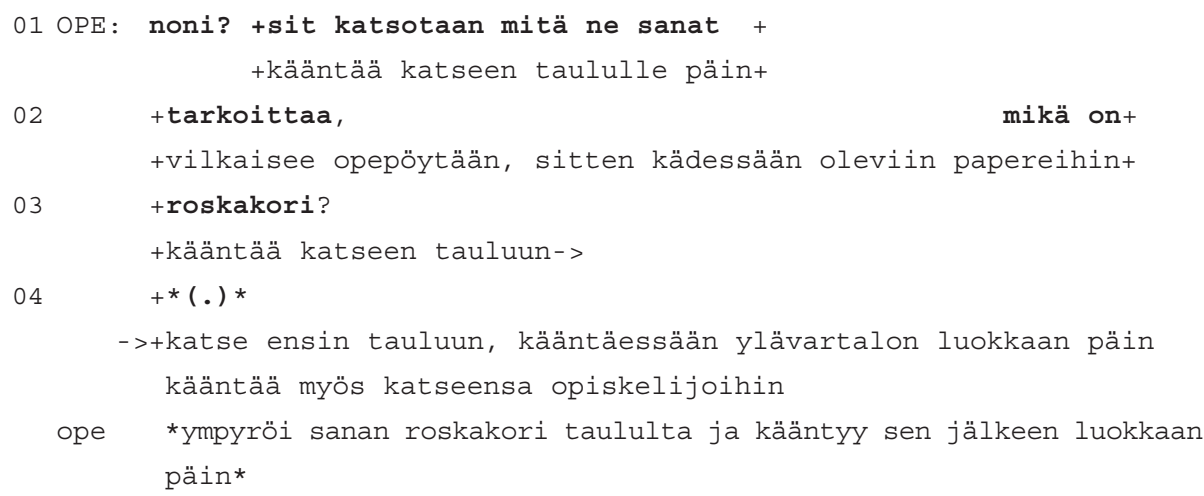

Siirryttäessä sanelutilanteen kirjoitusvaiheesta sanojen merkitysten läpikäyntiin opettaja ilmoittaa eksplisiittisesti, että on aika selvittää, mitä sanelun sanat tarkoittavat (r. 1-2). Hän myös esittää kieliopillisesti kokonaisen kysymyksen (mikä on roskakori?) siitä sanasta, jonka toivoo opiskelijoiden ensimmäiseksi selittävän. Lopuksi hän ympyröi kyseisen sanan taululta. (R. 2-4.) Kääntyessään luokkaan päin opettaja rakentaa tilanteen, jossa odotuksenmukainen seuraava vuoro on opiskelijoiden selitys. Yleensä hän ei kuitenkaan kysy enää myöhempien sanelun sanojen kohdalla, mitä sanat tarkoittavat vaan tyypillisesti ainoastaan ympyröi sanan taululta, sanoo sen ääneen ja kääntyy luokkaan päin, jolloin on odotuksenmukaista, että opiskelijat selittävät opettajan edeltävällä vuorollaan sanoman ja ympyröimän sanan.

Kun opettaja esittää kysymyksen, seuraavan vuoron puhuja valikoituu joko itsevalinnalla tai viittaamalla. Näistä edellinen on yksilön näkökulmasta tehokkaampi tapa mutta rajoittaa luokkayhteisön mahdollisuuksia osallistua tasavertaisesti. (Sahlström 1999: 123; Mortensen 2008: 191.) S2-oppituntikeskustelujen monenkeskisyys voi 
kaventaa oppilaiden mahdollisuuksia osallistua, sillä heidän täytyy kilpailla julkisista vuoroista ja oman vuoron tulee myös sopia muiden toimintaan. Toisaalta monenkeskisyys myös luo mahdollisuuksia osallistumiselle, koska osallistujat voivat hyödyntää oppitunneilla toisia oppijoita ja näiden vuoroja. Tällä tavoin oppilaat voivat lisätä ja monipuolistaa oppimismahdollisuuksiaan. (Lehtimaja 2012: 212-213.) Tämän artikkelin aineistossa vuorot jakaantuvat saneluaktiviteetin yhteydessä lähes poikkeuksetta itsevalinnalla tai joskus harvoin niin, että opettaja valitsee seuraavan puhujaksi osallistujan, joka ei ole pyytänyt vuoroa (vrt. Kääntä 2010: 127-132). Vuorojen jakautumiseen vaikuttaa varmasti se, että aineistoni opiskelijat ovat aikuisia ja näin jo lähtökohtaisesti tasa-arvoisemmassa asemassa opettajaan nähden kuin esimerkiksi peruskouluikäiset. Mahdollisesti merkitystä on myös sillä, kuinka sosiaalistuneita opiskelijat ovat koulun käytänteisiin (ks. Hellermann \& Harris 2015: 54).

Tarkasteluni kohteena olevat jaksot sisältävät lähes aina IRE/IRF (Initiation, Response, Evaluation/Feedback) -syklin. Näissä luokkahuonevuorovaikutukselle tyypillisissä toimintajaksoissa esimerkin 1 kaltaista opettajan aloitusta (initiation) seuraa sanan toiston lisäksi oppijoiden yhdessä rakentama ja monesta vuorosta koostuva responssi (response), johon opettaja vastaa arviolla ${ }^{6}$ (evaluation) tai palautteella (feedback). (Mehan 1979; Sinclair \& Coulthard 1975; Seedhouse 2004: 55-81.) Aivan kuten muutkin sekvenssit myös IRE-sekvenssit voivat laajentua monin tavoin, ja yleensä aineistoni IRE-/IRF-syklien sisällä onkin useita lyhyempiä toimintojaksoja (ks. sekvenssin laajentumisesta Schegloff 2007: 97-114). Vaikka sananselitys onkin odotuksenmukainen vuoro tässä kohdassa keskustelua opettajan vuoron jälkeen, kaikki sitä seuraava toiminta ei välttämättä ole sananselitystä, vaan mukana on esimerkiksi ymmärtämisen osoituksia ja selviä yksittäisiä kehollisia esityksiä. Joskus tapahtuu myös väärinymmärryksiä sanojen merkityksissä, ja aina opiskelijat eivät tiedä sanan merkitystä, jolloin opettaja tauon jälkeen pyrkii selittämään sen. On myös jonkin verran tapauksia, joissa opiskelijat kääntävät sanan muille kielille, mutta vaikka opettaja vaikuttaisi ymmärtävän käännöksen, hän ei välttämättä tartu siihen vaan odottaa usein lisää selittämistä.

\subsection{Substantiivien selittämisen rakentuminen luokkahuoneen vuorovaikutuksessa}

Esimerkissä 2 selitetään yhdyssanaa vesipullo. Opiskelijat ja tutkija istuvat hevosenkengän muotoisessa muodostelmassa niin, että he näkevät toistensa kasvot. Ryhmän naisten vieressä, opettajan näkökulmasta vasemmassa takanurkassa istuvan tutkijan pöydällä on vesipullo. Esimerkki havainnollistaa, kuinka konkreettisten substantiivien selitykset alkavat yleensä niin, että opiskelijat toistavat sanan, esittävät siihen liittyvää toimintaa ja tämän jälkeen tuovat mahdollisesti esille kehollisesti objektin muita ominaisuuksia, kuten ulkomuotoon eli kokoon ja muotoon liittyviä seikkoja. Vasta sitten aletaan tarvittaessa tarkastella sanahahmoa ja selvittää myös sanan semantiikkaa.

6. Heinonen (2017: 43) on käyttänyt tätä aihepiiriä käsittelevässä suomenkielisessä väitöskirjassaan käsitettä evaluointi kuvaamaan (myös) tätä niin sanottua kolmatta vuoroa. 
Esimerkki 2 alkaa aineistossa toistuvasta tilanteesta, jossa opettaja (OPE) on hyväksynyt opiskelijoiden edellisen selityksen ja kääntynyt tussitauluun päin. Hän sanoo noni (r. 1), joka on lyhennelmä dialogipartikkelista no niin; sen tiedetään osoittavan oppitunnilla usein siirtymää (Keravuori 1988: 45). Tämän jälkeen opettaja ympyröi tussitaululle kirjoitetun sanan vesipullo ja samanaikaisesti sanoo sen ääneen niin, että yhdyssanan edusosan sävelkulku on määriteosaa korkeampi (r. 1). Saed (SAE) ottaa seuraavan vuoron, mutta se on niin hiljainen, että kukaan ei osoita suuntautuvansa siihen. Saedin vuoron aikana opettaja kääntyy luokkaa kohti (r. 2), jolloin syntyy paikka sananselitykselle.

\section{(2a) Vesipullo}

\begin{tabular}{|c|c|c|c|c|c|}
\hline Kamera 2 & IB1 & YAF & AKR & SAL & ISM \\
\hline TUT & \multirow{5}{*}{\multicolumn{4}{|c|}{ OPE }} & $\mathrm{SAE}$ \\
\hline ZAR & & & & & - \\
\hline KAM & & & & & AHM \\
\hline AMI & & & & & HAS \\
\hline JAM & & & & & KAR \\
\hline Ovi & Kamera 1 & \multicolumn{3}{|c|}{ Taulu } & Opepöytä \\
\hline
\end{tabular}

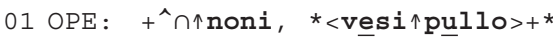

+katsoo tussitauluun---+

*ympyröi taululla

lukevan sanan vesipullo*

ib1 ^katse OPEen->

ism nkatse OPEen->

02 SAE :

$*+{ }^{\circ}$ vesi

* [vesi-

] (.) vesi- ves-०

ope *kääntyy luokkaan päin* +katse luokkaan päin->

olesittää tarttuvansa kaksin käsin kuvitteell. pullosta,

o2esittää avaavansa pullon korkin->

kuva

ope

kar

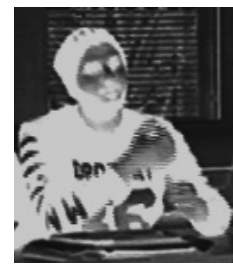

Kuva 1

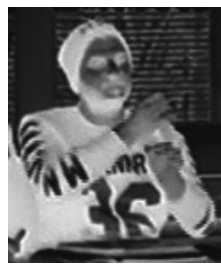

Kuva 2

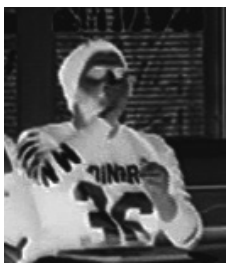

Kuva 3 
ope

ism

kuva

05 KAR: ->+vilkaisee YAFia +

oesittää

juovansao

\#kuva3

$\square$ katse OPEen->

\#((jatkaa\#puhetta arabiaksi)) $\Delta$

opetta $\triangle \# j \underline{a}: 0$

ธon pitelevinään pulloa kaksin käsin ja esittää juovansa

$\Delta$

kuva

\#kuva4

\#kuva5， \#kuva6

ope

+katsoo KARia->

ism

oesittää kiertävänsä

kuvitteellisen pullon

korkin kiinnio

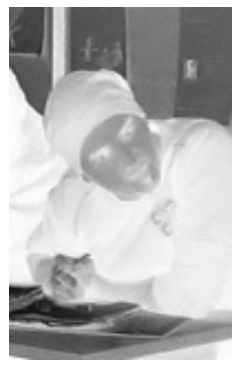

Kuva 4

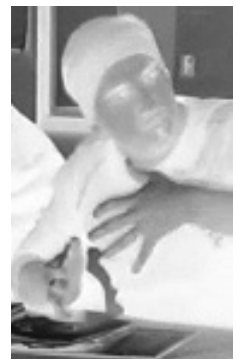

Kuva 5

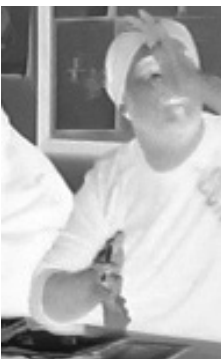

Kuva 6

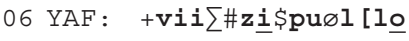

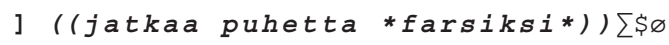

Easettaa vas. kät. n. kaulan korkeudelle ja oik. kät. otsan korkeudelle kämmenet vastakkain n. $25 \mathrm{~cm}$ päähän toisistaan $\Sigma$

kuva \#kuva7

sal \$levittää kämmenensä viistosti ylöspäin------------\$

ib1 ønostaa oikeaa kättään leuan korkeudelle ja takaisin--ø

ope ->+katsoo YAFia->

*nyökkää *

IB1

YAF

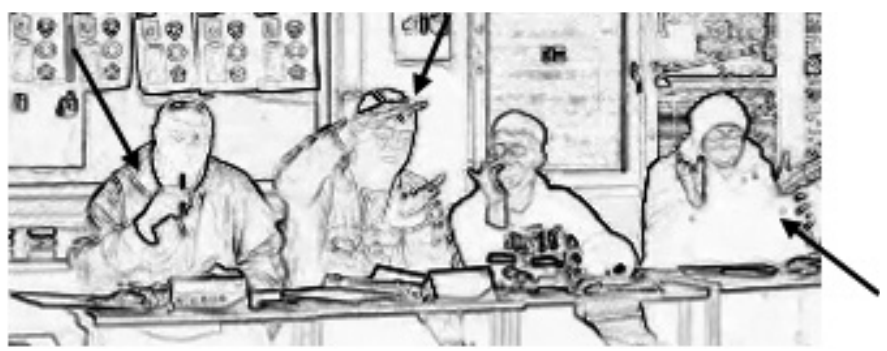

SAI

Kuva 7

07 IB1:

^[besipullo: ] 


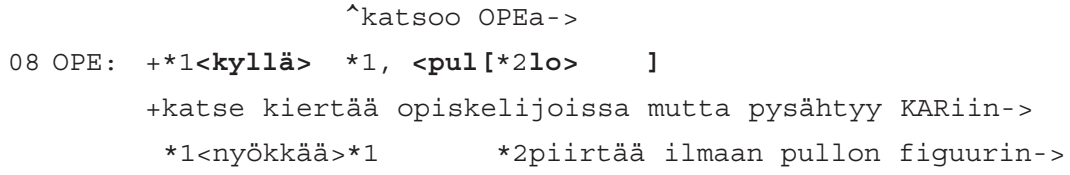

Varsinainen selityssekvenssi alkaa, kun Ismail (ISM) toistaa sanan vesipullo, esittää tarttuvansa molemmilla käsillään kuvitteellisesta pullosta, avaavansa kiertävällä kädenliikkeellä sen korkin, juovansa siitä ja sulkevansa kiertävällä eleellä korkin. Ismailin vuoron (r. 3) aikana Yafir (YAF) vilkaisee häneen, toistaa sen jälkeen sanan vesipullo ja kohdistaa sitten katseensa opettajaan (r. 4). Tämän jälkeen sanaa toistellaan lisää ja muutkin kuin Ismail jatkavat vesipullon ominaisuuksien selittämistä kehollisesti: Karim (KAR) hyvin samantapaisella juomiseleellä kuin Ismail on aiemmin tehnyt ja Yafir eleellä, joka ilmentää vesipullon kokoa (r. 4-6). Opettaja on katsonut niin Ismailiin (r. 3), Yafiriin (r. 4, 6) kuin Karimiinkin (r. 5) näiden elehtiessä ja arvioi heidän kehollisia vastauksiaan sekä verbaalisesti (r. 8) että kehollisesti nyökätessään kahdesti (r. 6, 8) ja elehtiessään pullon muotoa (r. 8).

Ismailin (r. 3-4) ja Karimin (r. 5) kehollisissa toiminnoissa on yhteistä se, että molemmissa substantiivia vesipullo lähestytään siihen liittyvän toiminnan kautta: vesipullosta juodaan, ja juotaessa pulloa täytyy kallistaa. Ismailin kierrekorkin avaamista esittävä ele myös rajaa sanaa: kyseessä ei voi olla esimerkiksi vesilasi, koska pullon korkki täytyy avata. Kehollisella toiminnalla myös rajataan joitakin juomia esityksen ulkopuolelle. Yafir ja opettaja taas lähestyvät vesipullon merkityksen selittämistä kehollisesti eri näkökulmista kuin Ismail ja Karim: he eivät esitä pulloon liittyvää toimintaa vaan sen visuaaliseen olemukseen liittyviä seikkoja. Yafir kuvaa kehollisella toiminnallaan ennemmin kokoa (r. 6) ja opettaja muotoa (r. 8-9).

Sanahahmo tuodaan huomion kohteeksi (r. 8), kun opettaja erottaa yhdyssanan vesipullo määriteosan sen edusosasta sanomalla ääneen pelkästään edusosan pullo, joka on vesipullon hyperonyymi.7 Näin huomio kiinnittyy yhdyssanan rakenteeseen (r. 9-11).

(2b)

09 KAR :

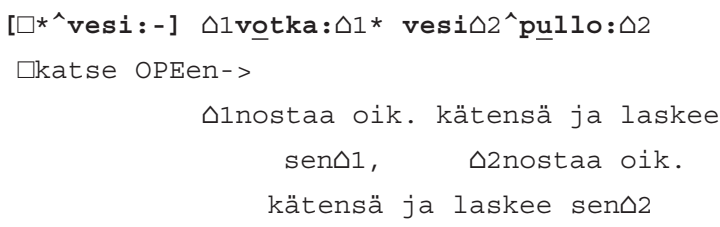

7. Vesipulloa voidaan pitää kiistattomasti yhdyssanana, koska sen määriteosa on substantiivin nominatiivimuoto (ks. ISK 2004 \$ 400). Puhutussa kielessä ero yhdyssanan ja sanaliiton välille voidaan tehdä usein myös painotuksella, mutta yhdyssanan määritteleminen on tällä tavalla silti suhteellista ja tulkinnanvaraista (V. Koivisto 2013: 329). 
$\Delta(.) \Delta$

kar $\Delta$ nyökkää $\Delta$

$11 \mathrm{KAR}: \Delta^{\wedge}$ sama $: \Delta^{\wedge}$

هnostaa molemmat kätensä yhtä aikaa ylös ja laskee ne alas $\Delta$

ib1 -> ^-.---^katsoo OPEa->

12 OPE: votkapulloh

$13 \mathrm{KAR}: \square \Delta+{ }^{\wedge} \Pi j \mathrm{joh} \square \mathrm{ho}+{ }^{\wedge} \Pi[$ hoho ]

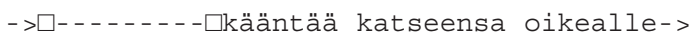

ธnyökkää ja kääntyy

oikealleه

ope ->+-------+alkaa kääntää katsetta keskemmälle luokkaa->

ib1 ->^-..-.-.-.^katsoo KARia->

yaf ->M-------Mvilkaisee KARia ja katsoo taas OPEa->

14 OPE: $\quad+$ [hehehe]

->+siirtää katseensa maahan->

\section{IBI: ^+botka haha haha}

^katse OPEen->

ope ->+katsoo IBI:een tai YAFiin->

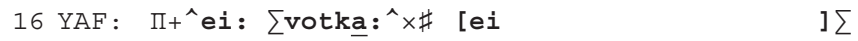

->Mkatse OPEen->

¿nostaa kämmenet vastakkain, n. 20 cm päähän toisistaan, vasen käsi päällä ja oikea alla---------々

ope ->+katsoo IB1:een tai YAFiin->

ib1 ->^--.----^siirtää katseen TUTiin->

tut $\quad$ kkatse IBI:een->

akr \#katse YAFiin->

17 IB1: 11 [shamppanjaa heehe^2he]

->^1.............-^2katse OPEen->

$18 \mathrm{OPE}:$ +*no esi\#merkik[si ]*

->+vilkaisee maahan ja katsoo IBl:een->

*levittää kätensä--.--.--.---**

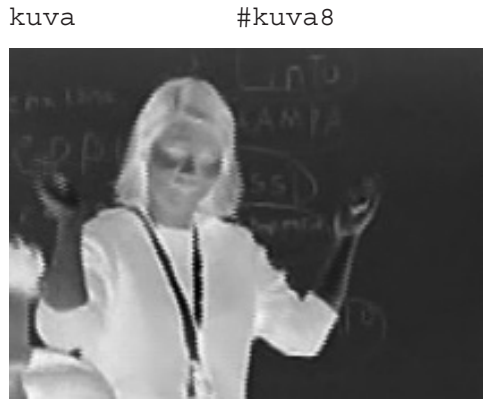

Kuva 8 


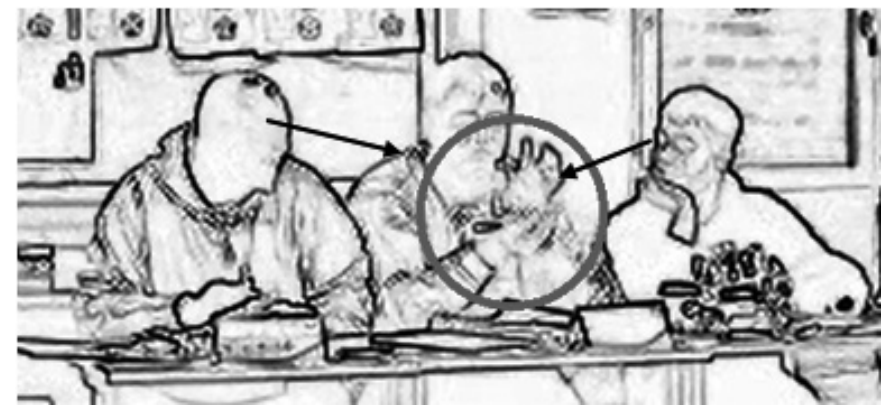

Kuva 9

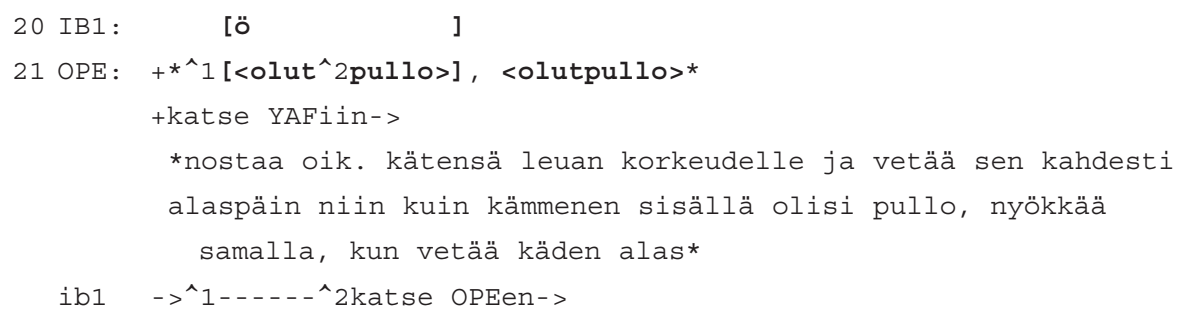

23 IB1: votka: votka: oludbullo

24 OPE: joo olutpullo

kaikki katse opEen

25 IB1: oluød ø

$$
\varnothing \text { nielaiseeø }
$$

Vuorossaan riveillä 9-11 Karim tuo keskusteluun mukaan votkapullo-sanan. Opettaja reagoi Karimin vuoroon sanomalla votkapullo (r. 12), mihin Karim puolestaan vastaa nyökkäämällä, sanomalla jooh ja nauramalla (r. 13). Karimin vuoro saa myös sekä opettajan (r. 14) että Ibrahimin (r. 15) nauramaan. Vaikuttaakin, että Karimin vuorolla on humoristinen funktio. Myös Ibrahim pyrkii toistamaan votka-sanan (r. 15) ja jatkaa vitsiä sanomalla shamppanjaa ja nauramalla (r. 17). Opettaja on siirtänyt tässä vaiheessa katseensa joko Ibrahimiin tai Yafiriin päin, ja hänen responssinsa on käsien le- 
vitys ja kommentti no esimerkiksi (r. 16-18). Huumori syntyy kulttuurisen tuntemuksen osoituksesta ja siitä, kuinka hyperonyymia pullo puretaan sen alkoholiin liittyviin alakäsitteisiin.

Yafir tuo vuorollaan keskusteluun uuden näkökulman, joka koskee pullon mahdollista sisältöä (r. 16, 19): jälkimmäisellä hän sanoo Karhu: Karhu: öö ja tekee samanaikaisesti eleen, jossa kämmenet ovat vastakkain ja noin 20 senttimetrin päässä toisistaan. Ele on hyvin samanlainen kuin hänen aiemmin (esim. 2a r. 6) tekemänsä, pullon kokoa esittävä ele, mutta kädet ovat nyt toisinpäin, lähempänä toisiaan ja hieman alempana: ylempi käsi on leuan korkeudella ja alempi rinnan korkeudella. Opettaja vaikuttaa kohtelevan vuorollaan (r. 21) Yafirin vuoroa kysymyksenä siitä, miten kutsutaan geneerisesti sitä pullokategoriaa, jonka sisällä on Karhu-merkkistä juomaa. Opettaja nimeää pullon olutpulloksi ja elehtii pullon kokoa ja muotoa vetämällä kuperassa muodossa olevia kämmeniään alaspäin niin, että vaikuttaa, että niiden sisällä olisi pullo. Sekä Yafirin (r. 19) että opettajan (r. 21) pullon kokoa esittävä elehdintä on tässä vaiheessa pienempää kuin aiemmin heidän elehtiessään vesipulloa (esim. 2a r. 6, 8-9); olutpullo onkin tyypillisesti vesipulloa pienempi. Yafir (r. 22) hyväksyy opettajan vastauksen kysymykseensä toistamalla sen määriteosan olut sekä ilmoittamalla, että opettajan selitys on riittävä sanomalla joo joo joo (ks. esim. A. Koivisto 2015: 127), nyökkäämällä ja tekemällä embleemin eli nostamalla peukalonsa pystyyn (claim of understanding, ks. Koole 2010). Yafirin kysymyksessä (r. 19) kielellinen ja kehollinen toiminta muodostavat kokonaisuuden, joka on enemmän kuin osiensa summa (ks. Goodwin 2007a: 198-199). Hän on aiemmin samassa tilanteessa (esim. 2a r. 6) tehnyt hyvin samantyyppisen esittävän eleen niin, että opettaja on nähnyt sen. Tuolloin hän on viitannut eleellään vesipulloon. Nyt hän hieman pienemmällä mutta muuten hyvin samantyyppisellä eleellä viittaa olutpulloon. Pelkällä eleellä ei kuitenkaan voi ilmaista, mitä nestettä pullon sisällä on. Yafir täsmentääkin nesteen laatua verbaalisesti viittaamalla tiettävästi vain oluen, ei muiden juomien, brändinä tunnettuun Karhuun. Kysymyksellään (r. 19) hän osoittaa myös kulttuurista tietoutta suomalaisesta olutbrändistä.

Sekä Karim (r. 9-11) että Yafir (r. 16, 19, 22) ilmentävät siis ymmärtävänsä jotain sanan rakenteesta: vesipullo on yhdyssana, jonka edusosa pullo voi saada myös muita määritteitä kuin vesi. Kaikkia merkitysaspekteja ei voida kuitenkaan esittää kehollisesti. Toisin kuin pulloa erilaisia juomia on vaikeaa elehtiä. Näin ollen kaikkien erilaisten juomien selittäminen tai niiden merkitysten ymmärtämisen osoittaminen rakentuu tilanteessa pääasiassa verbaalisen modaliteetin varaan. Oleellista on kuitenkin, että kehollinen toiminta näyttää opettajan vuoron toistamisen ohella olevan opiskelijoiden omaan kielelliseen tuottamiseen verrattuna ensisijaista: kehollinen juomistoiminta (r. 3-5) tapahtuu ensin ja tuo erityyppiset pullot ja erilaiset juomat ylipäänsä osallistujille mieleen ja relevanteiksi.

Esimerkissä 2 sanan vesipullo merkitystä lähdetään siis selittämään ensin toistamalla sana, sitten yksittäisen opiskelijan kehollisella toiminnalla, joka esittää objektiin liittyvää toimintaa, minkä jälkeen keholliseen toimintaan liittyy lisää osallistujia: ensin elehditään lisää vesipulloon liittyvää toimintaa, sitten vesipulloa kokoa ja muotoa. Tämän jälkeen opettajan aloitteesta huomio kiinnittyy sanan edusosaan pullo, minkä myötä opiskelijat pyrkivät sovittamaan osittain kielellä leikitellen veden lisäksi pul- 
lolle muitakin määritteitä, kuten votka ja olut. Lopuksi opiskelijat vielä toistelevat uusia esille nousseita sanoja, mitä voi pitää osoituksena siitä, että nämä sanat ovat heidän mielestään oppimisen - tai ainakin huomion saamisen - arvoisia.

\subsection{Verbien selitysten rakentuminen kehollisen esityksen keinoin}

Esimerkissä 3 selitettävä sana on avata, ja kyseisessä sanelussa on kirjoitettu vain verbejä. Ennen esimerkin jakson alkua opettaja on ympyröinyt sanan avata taululta ja toistanut sen verbaalisesti, mutta opiskelijat eivät vielä tässä vaiheessa ole suuntautuneet sanaan vaan rikas- ja rakas-sanojen eron pohtimiseen, johon myös opettaja on osallistunut. Opettaja kuitenkin palauttaa keskustelun huomion välisekvenssistä avataverbiin sanomalla okei? .hh no niin (r. 1), mikä implikoi tulevaa ja eteenpäin menemistä. Kysymällä mitä tarkoittaa avata (r. 1-2) opettaja rakentaa myös eksplisiittisesti paikan sanan selittämiselle. Esimerkki 3 eroaa sikäli aineiston tyypillisistä selitysjaksoista, että semantiikan kielelliseen tarkasteluun suuntaudutaan opiskelijan aloitteesta. Esimerkki havainnollistaa myös erityisen osuvasti, kuinka tärkeää on, että selitystä rakennetaan yhdessä ja kehollista esitystä toistetaan vielä useita kertoja sen jälkeen, kun yksittäiset opiskelijat ovat osoittaneet ymmärtäneensä sanan merkityksen (ks. Morton 2015: 267.)

(3a) Avata

\begin{tabular}{|c|c|c|c|c|c|}
\hline Kamera 2 & IB1 & YAF & $\mathrm{AKR}$ & $\mathrm{C}$ & - \\
\hline TUT & \multirow{5}{*}{\multicolumn{4}{|c|}{ OPE }} & SAE \\
\hline ZAR & & & & & - \\
\hline- & & & & & PIR \\
\hline AMI & & & & & MO1 \\
\hline JAM & & & & & KAR \\
\hline Ovi & Kamera 1 & \multicolumn{3}{|c|}{ Taulu } & Opepöytä \\
\hline
\end{tabular}

01

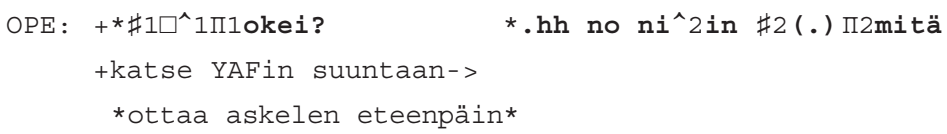


akr Osiirtää puhelimensa pulpetilleen->

ib1 ->^katse omiin muistiinpanoihin->

04 AKR: $\mathbf{0}_{+}{ }^{\wedge} \square<$ ava $+{ }^{\wedge} \square$ ta $>=0$

->0-- - - - - - - - -

ope ->+-----+katse AKRiin->

ib1 ->^----^^katse OPEen->

kar -> $\square-----\square$ katse AKRiin->

05 OPE : ^ $=$ ava*0\#ta *

*nyökkää *

ib1 ->^katse AKRiin->

akr Okääntää oik. kämmenensä pulpetin päällä kämmen ylöspäin-> kuva \#kuva10

06

\#(0.4...0\#0.6)

akr ->\#katse luokan oveen->

->Onostaa OK ilmaan->

kuva \#kuva11
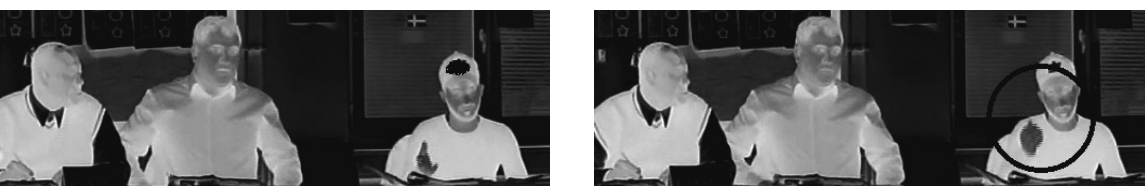

Kuva 10

Kuva 11

07 YAF : ПО1\#+1^(puhuu farsia*1)

d $2 \#+2$ *2^ava+3ta?

->Mvilkaisee PIRaa, katse OPEen->

akr ->0lpanee OK nyrkkiin ja vie sitä vasemmalle,

02palauttaa käden takaisin oikealle, ojentaa kämmenensä ylöspäin->

kuva \#kuva12

\#kuva13

ope ->+1vilkaisee YAFiin,

+2katse naisiin, +3katse YAFiin->

*1kohottaa molempia käsiään,

*2kääntää kehonsa naisia kohti, ojentaa oik. käsivartensa sormet kuperina heitä kohti->

ib1 ->^-..................-^^katse OPEen->

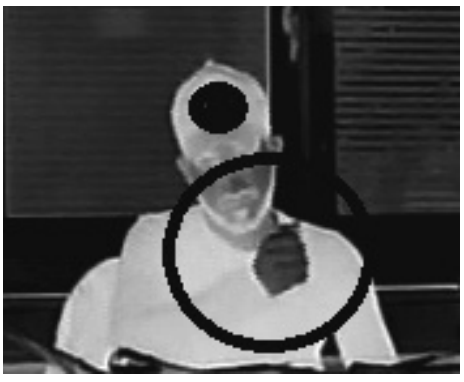

Kuva 12

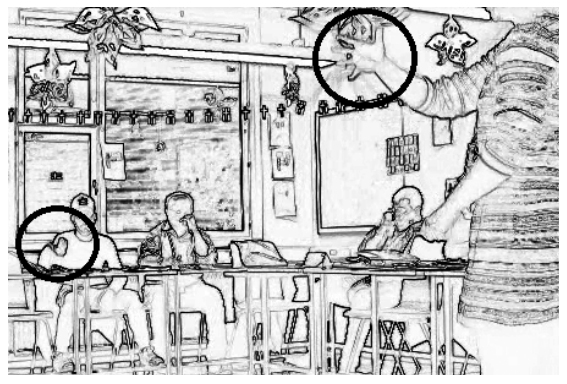

Kuva 13 


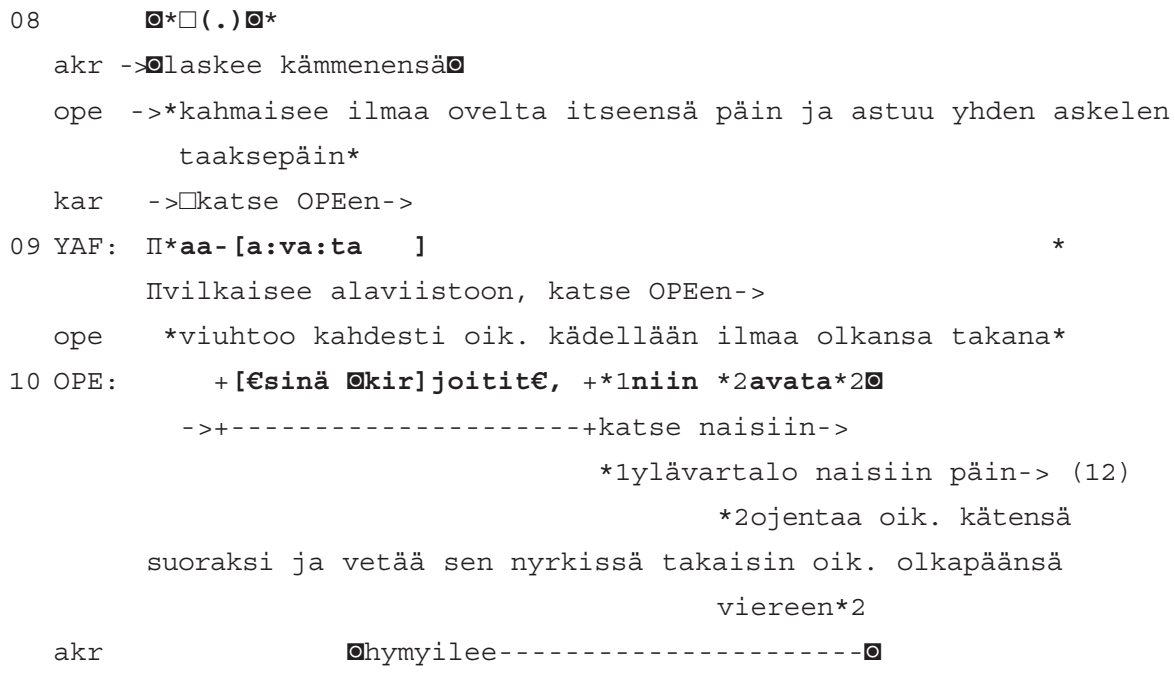

Opettajan katseen kohteena oleva Akram (AKR) ottaa opettajan vuoron jälkeen ensimmäisen vuoron sanomalla a vata, mitä opettaja kohtelee todennäköisesti opiskelijan varmistuksena sanahahmosta toistaessaan sanan itsekin (r. 4-5). Tämän jälkeen seuraa Akramin vastausehdokas, kehollinen esitys, jossa hän suuntaa katseensa luokan oveen ja oikealla kädellään tekee eleen, jonka voi nähdä esittävän oven avaamista (r. 6-7). Akramin kehollinen toiminta on kehollista esittämistä, koska ensinnäkin se muodostaa kokonaisuuden, joka koostuu useista erilaisista kehollisista komponenteista: sen merkitys syntyy sekä Akramin katseen suunnasta että kädellä tapahtuvasta toiminnasta. Toiseksi Akram nimenomaan esittää oven avaamista sen sijaan, että kävelisi luokan ovelle ja avaisi sen, mikä olisi myös periaatteessa mahdollista. Näin ollen Akramin toiminta on kehollisen esittämisen määritelmän mukaista hypoteettisen skenaarion esittämistä (ks. Tai \& Brandt 2018: 2). Opettaja tuottaa kaksi hyvin samantyyppistä mutta suurieleisempää kehollista esitystä (r. 7-8, 10): hän kääntää vartalonsa omasta näkökulmastaan katsottuna vasemmalla puolella olevia, lähellä ovea istuvia naisia kohti, kahmaisee ilmaa ja vie kätensä oikean olkapäänsä viereen. Kehollisella toiminnallaan, jota on kuvattu litteraatissa riveillä 7-8, opettaja vahvistaa Akramin vastausehdokkaan oikeaksi: vaikka hänen kehonsa liikerata kohdistuukin oven puoleiseen seinään, hänen katseensa suuntautuu koko ajan Akramiin, ja näin ollen vuoron vastaanottaja on ennen kaikkea Akram. Toisaalta se, että opettaja toistaa saman esityksen katse ja ylävartalo kohdistettuina eri suuntaan (r. 10), kertoo siitä, että kehollisella toiminnallaan hän pyrkii varmistamaan, että mahdollisimman moni opiskelija näkisi kehollisen esityksen ja näin ymmärtäisi avata-verbin merkityksen (ks. Råman 2018: luku 4).

Sekä opettajan että Akramin toiminta on monifunktioista. Akramin kehollinen esitys näyttäytyy paitsi vastauksena myös ymmärrysehdokkaana: toisaalta hän osoittaa toiminnallaan ymmärrystä mutta samaan aikaan pyytää siihen myös vahvistusta, jonka saatuaan hymyilee ja osoittaa näin tyytyväisyyttään (r. 10). Opettaja puolestaan sekä vahvistaa Akramin vastauksen oikeaksi että pyrkii saamaan mahdollisimman monen muunkin ryhmän jäsenen ymmärtämään, mitä sana tarkoittaa. On kiinnostavaa, että tämä jakso ra- 
kentuu pelkästään sanan avata toistelun ja kehollisen toiminnan varaan. Toisaalta se, mitä riveillä 7-10 kuvatussa jaksossa ennen kaikkea kielellisesti tapahtuu, muotoutuu opettajan ja Yafirin (YAF) keskinäiseksi välisekvenssiksi. Siinä Yafir ilmeisesti kommentoi farsin kielellä kirjoittaneensa jotain ja opettaja vahvistaa tämän kielellisesti samanlinjaisella vuorollaan (r. 10) ja kehollisesti viuhtomalla oikealla kädellään olkansa yli taulun suuntaan (r. 9). Opettajan ele on metaforinen: olan yli viuhtomisen voi nähdä viittaavan menneeseen, taaksejääneeseen tapahtumaan (ks. Tai \& Khabbazbashi 2019a: 451-456).

Tyypillisesti aineistossa sanat sidotaan kielelliseen kontekstiin opettajan aloitteesta, mutta seuraavassa katkelmassa tämän tekee opiskelija (r. 11).

(3b)
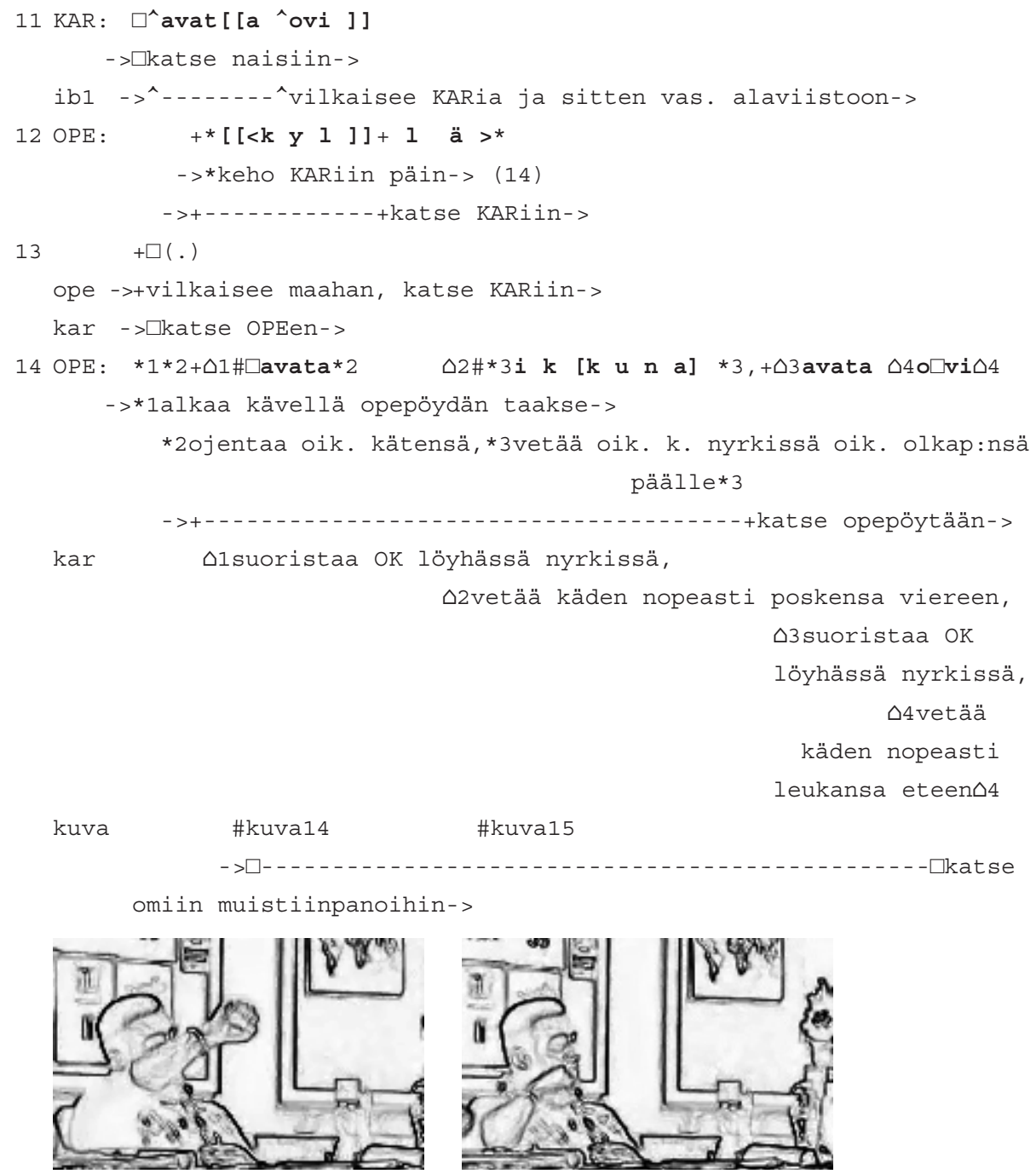

Kuva 14

Kuva 15 
Akramin (esim. 3a r. 4-6) ja opettajan (esim. 3a r. 8-10) kehollisia esityksiä aiemmin katseellaan seurannut Karim (KAR) tuottaa lausuman avata ovi (r. 11), jolla hän kielentää Akramin ja opettajan aiemman kehollisen esittämisen. Opettaja vahvistaa tämän Karimin vuoron kääntäessään kehonsa ja katseensa Karimiin päin ja sanomalla kyllä (r. 12), täydentämällä Karimin vuoroa toistaen hieman muokattuna aiemman kehollisen toimintansa (r. 14) ja sanomalla avata ikkuna, avata ovi. Koska opettaja katsoo avata-verbin käyttöä havainnollistaessaan (r. 14) Karimiin eikä esimerkiksi ikkunaan tai oveen, hän jättää kehollisessa toiminnassaan spesifioimatta avattavan objektin: esimerkiksi ikkuna tai ovi voidaan avata näin. Karim ja opettaja rakentavat opettajan vuoron (r. 14) aikana yhdessä kehollista esitystä: heillä on toiminnan aikana tiivis katsekontakti, ja Karimin kehollinen toiminta on niin ajoitukseltaan kuin liikeradaltaankin hyvin samantyyppistä opettajan toiminnan kanssa.

Karimin tavoin selityssekvenssin alussa Akramin ja opettajan kehollista toimintaa aktiivisesti katseellaan seurannut Ibrahim (IB1) osallistuu keskusteluun sanomalla avata (r. 15), mitä opettaja kohtelee dialogipartikkelillaan Ibrahimin pyrkimyksenä varmistaa, että on ymmärtänyt, mikä keskustelussa analysoitava sana on ja miten se äännetään (r. 16).

(3c)

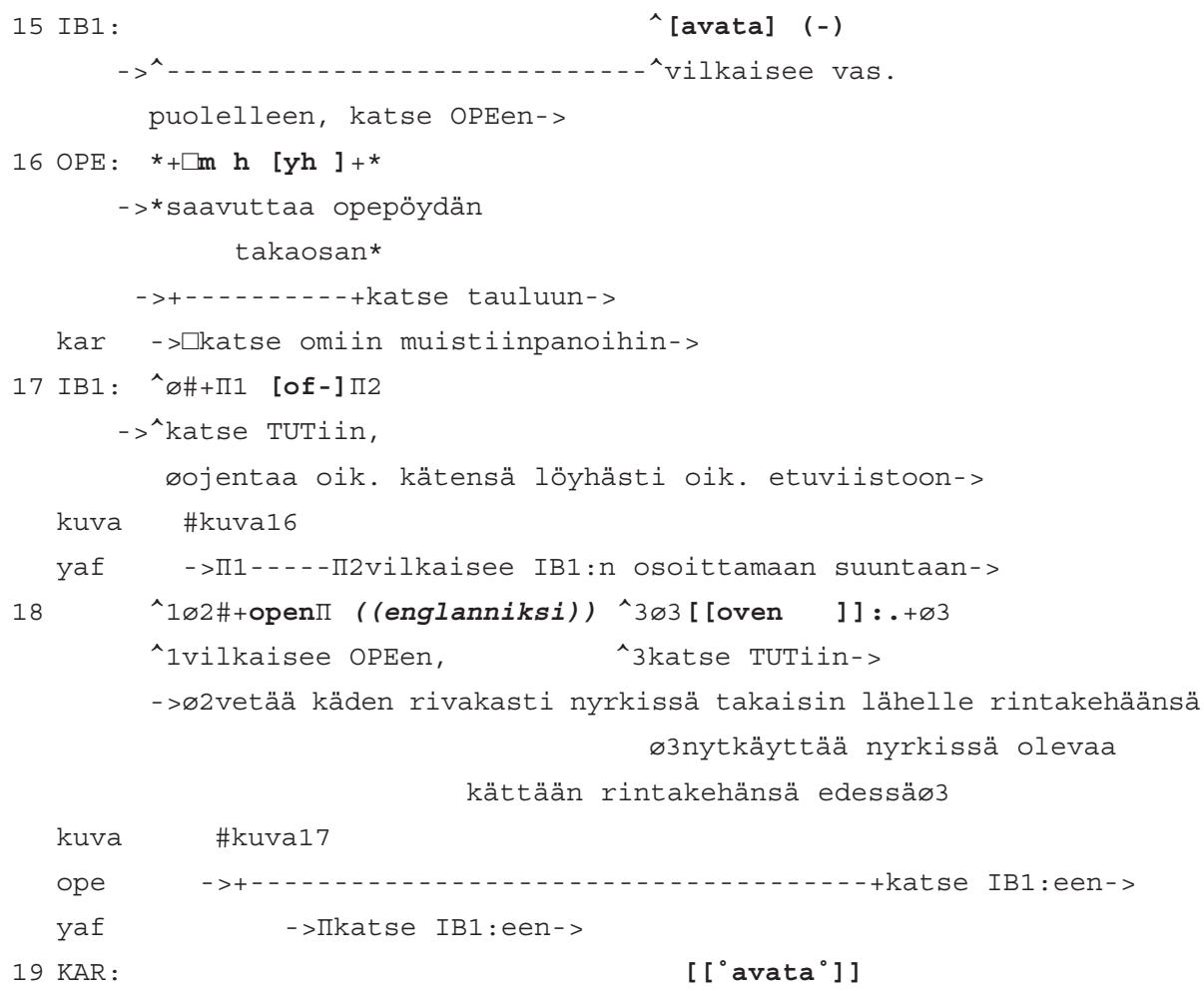




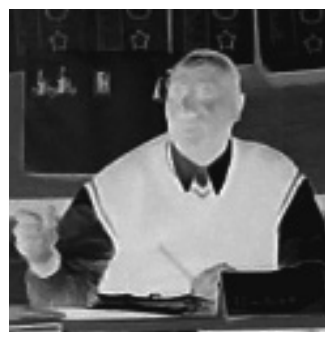

Kuva 16
Kuva 17

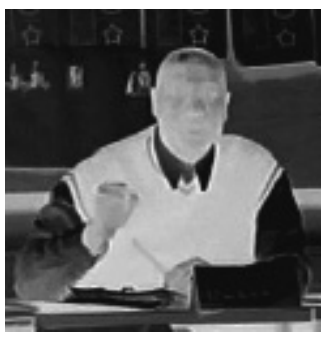

$20 \mathrm{OPE}: \quad+1^{\wedge} \square \Pi<\mathrm{kyllä}>+2 \varnothing, \mathrm{ky} l \mathrm{lä} \varnothing \square$, joo

->+1vilkaisee IB1:een,

+2 katse tauluun->

ib1 $->^{\wedge} k a t s e$ OPEen->

ønÿkkää

kahdestiø

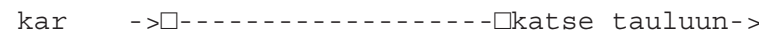

yaf $\quad->$ Mkatse OPEen->

$21 \mathrm{YAF}$ : avata hh

22 IB1: ^ 1 oven, oven, oven ${ }^{\circ}$ ` 2 avata oven.

->^1vilkaisee vasempaan viistoon, ^2katse TUTiin->

Muut osallistujat vaikuttavat jo orientoituvan keskustelussa seuraavaan siirtymään, mutta Ibrahim varmistaa vielä uudelleen verbin merkityksen kääntämällä sen englanniksi ja pelkän toistamisen lisäksi myös taivuttamalla ovi-sanaa keskustelussa aiemmin käytetyn päätteettömän akkusatiivin sijaan genetiivipäätteiseksi akkusatiiviksi oven (r. 18). On oletuksenmukaista, että Ibrahim muistaa genetiivipäätteisen akkusatiivin jostain aiemmasta tilanteesta, todennäköisemmin käytettynä yksikön ensimmäisen persoonan yhteydessä ('minä avaan oven'). Muoto oven ei ole tässä yhteydessä kieliopillisesti oikea mutta osoittaa, että Ibrahimilla on muistijälki siitä, miten avata-verbiä voidaan käyttää. Myös hän tekee kahdesti oven avaamista esittävän eleen ja osoittaa katseellaan, että kaipaa vuorolleen opettajan vahvistusta. Opettaja kääntääkin katseensa Ibrahimiin tämän vuoron loppupuolella ja vahvistaa tämän ymmärrysehdokkaan oikeaksi vielä aiempaa selvemmin sanomalla kyllä, kyllä, joo (r. 20). Lopuksi opiskelijat vielä toistelevat avata-verbiä sellaisenaan (r. 21) ja esimerkkilausekkeessa (r. 22).

Esimerkin 3 avata-sanan selitys alkaa siis niin, että opettajan huomion kohteeksi tuoma sana toistetaan ja opiskelija tuottaa kehollisen esityksen, jolla hän ilmentää sanan merkitystä ja osoittaa ymmärtämistä kuitenkin pyytäen samalla vahvistusta. Opettaja tuottaa hyvin samantyyppisen kehollisen esityksen ja samalla vahvistaa opiskelijan kehollisen vastaus- ja ymmärrysehdokkaan oikeaksi. Tämän jälkeen sanaa käytetään opiskelijan aloitteesta erilaisissa multimodaalisissa esimerkkilausekkeissa, jotka selventävät sanan merkitystä. Yksittäinen kehollinen esitys tai ymmärryksen osoitus ei näin ollen riitä päättämään sekvenssiä, vaan useat opiskelijat osallistuvat sanan multimodaaliseen selittämiseen ja toisteluun luoden näin omaa henkilökohtaisempaa suhdettaan sanaan. 


\section{Yhteenvetoa ja pohdintaa}

Olen tässä artikkelissa analysoinut sananselitysten rakentumista aikuisten luku- ja kirjoitustaidon koulutuksessa ja fokusoinut nimenomaan opiskelijoiden selitystoimintaan. Sananselityssekvenssit sijoittuvat aineistossani aikuisten lukutaitokoulutukselle tyypillisen pedagogisen aktiviteetin, sanelun, yhteyteen. Saneluiden sanat ovat yleensä substantiiveja tai verbejä. Odotuksenmukainen paikka sananselitykselle rakentuu, kun opettaja ilmoittaa, että seuraavaksi käydään yhdessä läpi taululle kirjoitettujen sanojen merkitykset, hän ympyröi sanan, sanoo sen ääneen ja kääntyy luokkaan päin. Myös aiemman tutkimuksen mukaan sananselityssekvenssi alkaa tyypillisesti siitä, että opettaja tuo tietyn sanan yhteisen huomion kohteeksi (Mortensen 2011; Morton 2015; Tai 2018; Waring ym. 2013).

Analyysissa osoitin, että tämän jälkeen opiskelijat toistavat sanan (ks. myös Mortensen 2011; Tai 2018). Toiston jälkeen tyypillisesti yksi opiskelijoista tuottaa esittävän eleen (esimerkissä 2 vesipullo) tai kehollisen esityksen (esimerkissä 3 avata). Tätä seuraa muiden osallistujien kehollinen toiminta (joko opiskelijan tai opettajan tuottama), ja yleensä opettajan aloitteesta siirrytään sanan semanttiseen tarkasteluun verbaalisin keinoin. Samaisella vuorolla opettaja tyypillisesti antaa sekä sanallisesti että kehollisesti palautteen tai arvion opiskelijoiden kollektiivisesti rakentamasta responssista. Näin ollen sananselityssekvenssi sisältää myös (laajentuneen) IRE/IRF-toimintojakson (ks. Mortensen 2008: 179). Yleensä opiskelijat alkavat vasta opettajan arvion tai palautteen jälkeen kielellisen resurssin varassa selvittää sanan semantiikkaa. Sitä tarkastellaan kielellisten esimerkkien avulla, ja aivan lopuksi opiskelijat tyypillisesti vielä toistelevat sanaa. Täten opiskelijoiden fokusoituminen sanan verbaaliseen selittämiseen tapahtuu aineistossani toistoa lukuun ottamatta myöhään verrattuna niihin tuloksiin, joita on saatu aiemmasta luokkahuoneen sananselityksiä käsittelevästä tutkimuksesta (Mortensen 2011; Morton 2015; Tai 2018; Tai \& Khabbazbashi 2019a, 2019b; Taşkin 2017; Waring ym. 2013).

Mikäli selitettävä sana on konkreettinen substantiivi (vesipullo), sitä esittävä elehdintä liittyy yleensä objektilla tehtävään toimintaan. Näin tehdään useimmiten silloinkin, kun tällainen objekti olisi luokkahuoneessa opiskelijoiden potentiaalisen näköhavainnon ulottuvilla kuten esimerkissä 2 käsitelty vesipullo (ks. objektien havaittavuudesta aistein Nevile, Haddington, Heinemann \& Rauniomaa 2014: 5). Tyypillisesti opiskelijat lähtevät siis selittämään sanoja kehollisen toiminnan kautta, joten se on analysoimissani toimintojaksoissa ensisijaista suhteessa kielelliseen toimintaan. Luokkahuoneen objektit taas tulevat merkityksellisiksi vasta, kun niitä käytetään. Opiskelijat eivät kuitenkaan analysoimieni jaksojen perusteella vaikuta yleensä orientoituvan luokkahuoneen objekteihin, elleivät ne kuulu aivan ilmeisesti luokan kalustoon tai opiskeluun, kuten ovi, ikkunat ja tuolit tai taulu, kynät ja paperit. Aikaisemmassa monikielisten luokkahuoneiden sanan- tai käsitteenselityksiä tarkastelevassa tutkimuksessa (Heller 2016; Majlesi 2015; Mortensen 2011; Morton 2015; Sert 2015; Waring ym. 2013; Tai 2018; Tai \& Khabbazbashi 2019a, 2019b) vastaavia havaintoja ei ole tehty, vaikka selittämisen multimodaalinen luonne onkin sinänsä tunnustettu. Aiemmassa tutkimuksessa fokus on myös ollut edistyneemmissä tai ainakin akateemisesti 
harjaantuneemmissa oppijoissa, mikä todennäköisesti vaikuttaa esimerkiksi substantiivien abstraktiotasoon. Näin ollen sanojen abstraktiuteen pohjautuva jako analyyttisiin ja animoituihin (Waring ym. 2013) selityksiin ei tässä tutkimuksessa tule samalla tavalla näkyviin.

Tyypillisesti opettaja päättää, milloin sanaa on selitetty tarpeeksi ja voidaan siirtyä eteenpäin (ks. myös Morton 2015; Waring ym. 2013). Toisaalta esimerkissä 3 näkyy myös se, kuinka opiskelijat saattavat haluta vielä jatkaa selityssekvenssiä, kun opettaja orientoituu jo uuteen sanaan. Selitettävän sanan käyttäminen kontekstissa, tyypillisimmin joko todellisessa tai kuvitteellisessa esimerkkilauseessa, vaikuttaakin olevan tärkeä osa selityssekvenssiä, vaikka kontekstualisoinnin paikka sekvenssissä vaihteleekin (Morton 2015; Waring ym. 2013; Tai 2018). Aineistossani on jonkin verran jaksoja, joissa sanan toiston jälkeen opiskelija alkaa rakentaa selitystä ensisijaisesti käännöksen tai (hyvin harvoissa tapauksissa) suomenkielisen puheen varaan. Samoin kuin aiemmassa luokkahuonekontekstissa tapahtuvia sananselityksiä käsittelevässä tutkimuksessa (Mortensen 2011; Morton 2015; Tai 2018; Waring ym. 2013; Taşkin 2017) myös analysoimassani aineistossa opiskelijat kääntävät siis sanan usein muille kielille, yleisimmin arabiaksi. Yhteisen ymmärryksen muodostamisen kannalta se ei ole kuitenkaan samalla tavalla odotuksenmukaista tai sanan merkitystä selittävää toimintaa kuin aiemmassa tutkimuksessa, sillä tämän aineiston osallistujien mahdollisuudet käyttää suomen lisäksi muita yhteisiä kieliä ovat hyvin vähäiset. Joskus opettaja vaikuttaa ymmärtävän käännöksen (vaikka ei omien sanojensa mukaan sujuvasti osaakaan arabiaa), mutta ei yleensä hyväksy sitä riittäväksi selitykseksi vaan edellyttää lisää selittämistä joko suomeksi, kehollisesti tai ympärillä olevia materiaalisia resursseja hyödyntäen (ks. myös Taşkin 2017). Kehollisuus on analysoimissani jaksoissa kaikkien osallistujien yhteinen resurssi, sillä hevosenkengän muotoisen istumajärjestyksen vuoksi jokaisella osallistujalla on mahdollisuus havaita toisten kehollista toimintaa ja tuottaa toisten nähtäväksi omaa kehollista toimintaansa. Näin kehollisella toiminnalla voidaan selittää sanojen merkityksiä paitsi opettajalle myös muille opiskelijoille.

Aineistoni perusteella joidenkin konkreettisten esineiden nimiä tai fyysistä toimintaa kuvaavia verbejä voidaan siis selittää yhdessä hyvin vähäisiäkin kielellisiä resursseja hyödyntäen niin, että osallistujien välille muodostuu tilanteessa riittävä yhteisymmärrys. Analyysissani nousikin esille myös kysymys siitä, mikä on sananselityksen, ymmärtämisen osoituksen (display of understanding) ja kehollisen esittämisen keskinäinen suhde. Analysoimieni toimintojaksojen perusteella näiden välille ei voi tehdä selvää rajanvetoa, vaan ne limittyvät toisiinsa. Samoin kuin aiemmassa tutkimuksessa on havaittu (Koole 2010; Morton 2015), tässäkään analysoimani selityssekvenssit eivät kuitenkaan pääty pelkkään yksittäiseen ymmärtämisen osoitukseen tai keholliseen esittämiseen, vaan ne voivat sisältää useita selittäviä vuoroja, jolloin yksittäisten ymmärtämisen osoitusten ja kehollisten esittämisten voi nähdä jäsentyvän sananselityksiä pienemmiksi merkityskokonaisuuksiksi. Selityssekvenssi puolestaan rakentuu nimenomaan kollektiivisesti ja muiden vuoroja hyödyntäen (ks. Koole 2010; Kääntä ym. 2018; Merke 2016; Mortensen 2011; Morton 2015). Toisaalta taas yksittäinenkin kehollinen esittäminen on enemmän kuin pelkkää ymmärtämisen osoittamista tai sanan merkityksen selittämistä: sillä luodaan kytkös luokkahuoneen ulko- 
puolelle ja näin myös toiseen tilanteeseen, jossa sanaa voisi idiomaattisesti käyttää (ks. Tai \& Brandt 2018: 2). Painopiste aikaisemmassa kielenoppimiskontekstissa tapahtuvia multimodaalisia sananselityksiä koskevassa tutkimuksessa on kuitenkin ollut nimenomaan opettajien selitystoiminnassa (Mortensen 2011; Morton 2015; Waring ym. 2013). On mahdollista, että tämä liittyy juuri siihen, miten määrittelemme sananselityksen: lähtökohtaisesti opettaja taitaa oppijoita paremmin kohdekielen ja hänen tehtävänsä on myös tarjota oppijoille mahdollisimman paljon tilaisuuksia kuulla kieltä. Näin ollen voi olla, että opiskelijat turvautuvat selitystoiminnassaan opettajaa todennäköisemmin muihin kuin verbaalisiin resursseihin.

Kaikki opiskelijat eivät tämänkään tutkimuksen aineistossa välttämättä osallistu kovin näkyvästi yhteiseen selittämiseen. Siksi onkin tärkeää muistaa, että myös toistaminen on osallistumista (ks. Lehtimaja 2012). Toistamalla sanan opiskelijat osallistuvat avainsanojen määrittämiseen ja selityssekvenssin rakentumiseen ja osoittavat kohtelevansa tällaista sanaa tilanteen etenemisen kannalta relevanttina (ks. Mortensen 2011: 149-150, 155). Toistelemalla huomion kohteeksi tuotua sanaa he luovat siihen myös itse kiinteämpää suhdetta. On myös todettu, että imitatiivinen toisto on tärkeää luku- ja kirjoistustaidon opiskelijoiden kielitaidon kehitykselle (Tammelin-Laine 2014a: 28, 33; ks. myös Toisto-metodista Möttönen \& Ahlholm 2018). Siksi on tärkeää, että opiskelijat saavat toistella sanoja, vaikka se saattaisi yhteisen keskustelun etenemisen näkökulmasta vaikuttaa joskus irrelevantilta. Myös huumori voi auttaa sanojen mieleen painamisessa ja näin myös oppimisessa (ks. esim. Lehtimaja 2012: 128-141), joten leikitteleville vuoroille on toisen kielen oppimisessa paikkansa, etenkin kun ne ovat opiskelijoista lähtöisin.

Tämän artikkelin vuorovaikutuksen yksityiskohtaiseen tarkasteluun perustuvassa analyysissa on noussut pinnalle erityisesti oppimis- ja opiskelutoiminnan kehollisuus. Omaa kehoa hyödynnetään sananselityksissä jopa todennäköisemmin kuin luokkahuoneen materiaalisia resursseja, vaikka näkyvillä olevia objekteja osoittamalla selittäminen olisi lähtökohtaisesti yksinkertaisempaa ja taloudellisempaa. Tässä mielessä luokkahuonetta voidaan pitää materiaalisesti "köyhänä" ympäristönä. Vaikka oppimisympäristöt kehittyvät koko ajan, ei ole vielä odotuksenmukaista, että luokkahuoneessa olisi kovin paljon luokan ulkopuolisissa tilanteissa käyttämiämme esineitä (ks. arjen toimintaympäristöjen hyödyntämisestä kielenoppimisessa Lilja \& Piirainen-Marsh 2019). Sen sijaan oletamme, että luokassa on pulpetteja, (liitu)taulu ja jokaisella opiskelijalla omat muistiinpanovälineet, joita puolestaan tarvitsemme vain vähän luokan ulkopuolella. Kehollisuuden korostuminen saattaa olla kytköksissä myös siihen, että kyseessä ovat nimenomaan suomen kielen ja lukutaidon opiskelijat. Opittavan asian semanttinen merkitys, merkityksen ymmärtäminen ja merkityksellisyys oppijalle itselleen ovat lukutaito-opiskelijoille erityisen oleellisia (Tammelin-Laine 2014a: 67-68; Tarone ym. 2009: 110, 116-117). Mahdollisesti opiskelijat eivät koe pelkkää esineen osoittamista riittävän mielekkäänä tai motivoivana toimintana, vaan asioille etsitään todellisia merkityksiä.

Tunnustamme laajasti kehon hyödyntämisen aikuisten oppimisessa ja ohjaamisessa, kun harjoitellaan esimerkiksi tanssia (Keevallik 2013), itsepuolustus- ja kamppailulajeja (Råman 2018; Råman \& Haddington 2018) tai muuta selvästi fyy- 
sistä taitoa. Monenlaisia kehollisuuden ja suullisen kielitaidon oppimista integroivia hankkeita on meneillään myös käytännön pedagogiikassa (ks. esim. Sirkuksesta siivet elämään -hanke, ks. Lilja, Laakkonen, Sariola \& Tapaninen 2020; TALK-hanke, ks. TALK; toiminnalliset perhekerhot, ks. Kotoklubi Kaneli; LALI-projekti, ks. Mutta, Peltonen, Lefebvre, Nyikos, Hackl \& Varhegyi 2019), ja useat alan opettajat ovat jo pitkään olleet tietoisia erilaisista toiminnallisista menetelmistä ja käyttäneet niitä (ks. esim. Moilanen 2002). Silti aihepiiristä on vain hyvin vähän tutkittua tietoa (ks. kuitenkin laulamisesta Alisaari 2016; kotiäitien kurssista Intke-Hernández \& Holm 2015; ruoanlaitosta Kurhila \& Kotilainen 2017; ks. myös kielenoppisesta luokan ulkopuolella yleisemmin Kotilainen, Kurhila \& Kalliokoski toim. 2019; sosiaalisesta sirkuksesta Lilja ym. 2020; käytännön tarpeiden myötä kehitetystä Toisto-menetelmästä Möttönen \& Ahlholm 2018). Oma keho on kuitenkin aina mukana kulkeva vuorovaikutuksen ja oppimisen resurssi, jota hyödyntäen voidaan rakentaa merkityksiä, yhteistä ymmärrystä toisten kanssa sekä oppia kieltä esimerkiksi eleitä (Eskildsen \& Wagner 2013, 2015, 2018) tai pantomiimia käyttäen (Hellermann 2018). Todennäköisesti luokassa tapahtuvilla kehollisilla esityksillä voidaankin tuoda luokkahuoneen sisäisiä ja ulkoisia kielenkäyttötilanteita lähemmäs toisiaan (Tai \& Brandt 2018: 2). Kehollisuus on keskeistä lukutaitokoulutuksen vuorovaikutuksessa, ja se kytkeytyy tiiviisti myös kielenkäyttöön ja -oppimiseen. S2-lukutaito-opiskelijan mahdollisuudet tukeutua kielenoppimisessa aiempaan kouluhistoriaansa ja kirjallisiin taitoihin, erityisesti muistin tukena, ovat rajalliset (Tammelin-Laine 2014a: 18-19). Siksi on tärkeää jatkossa tutkia pitkittäisesti, miten tämän viiteryhmän opiskelijat hyödyntävät kielenoppimisessaan kehollisia ja materiaalisia resursseja mahdollisesti muistamista tukeakseen ja millaiset oppimisympäristöt ovat heille suotuisimpia.

\section{Lähteet}

Ahvenainen, Ossi - Holopainen, Esko 2014: Lukemis- ja kirjoittamisvaikeudet. Teoreettista taustaa ja opetuksen perusteita. Jyväskylä: Special Data.

Alis A ARI, JENNI 2016: Songs and poems in the second language classroom. The hidden potential of singing for developing writing fluency. Annales Universitatis Turkuensis. Series B Humaniora 426. Turku: Turun yliopisto. https://www.utupub.fi/handle/10024/128287.

BeLHiAh, Hassan 2013: Using the hand to choreograph instruction. On the functional role of gesture in definition talk. - Modern Language Journal 97 s. 417-434.

Clark, Herbert H. 2016: Depicting as a method of communication. - Psychological Review 123 s. 324 - 347. http://dx.doi.org/10.1037/revooooo26.

Compernolle, Rèmi A. VAn - Smotrova, Tetyana 2017: Gesture, meaning, and thinking-for-teaching in unplanned vocabulary explanations. - Classroom Discourse $8 \mathrm{~s}$. 194-213.

Dalton-Puffer, Christiane 2007: Discourse in Content and Language Integrated Learning (CLIL) classrooms. Amsterdam: John Benjamins. https://doi.org/10.1075/1llt.20.

Erath, Kristin - Prediger, Susanne - Quasthoff, Uta - Heller, Vivien 2018: Discourse competence as important part of academic language proficiency in mathematics classrooms. The case of explaining to learn and learning to explain. - Educational 
Studies in Mathematics 99 s. 161-179.

ESKILDSEN, SøREN Wind - WAgNeR, JohANNES 2013: Recurring and shared gestures in the L2 classroom. Resources for teaching and learning. - European Journal of Applied Linguistics 1 s. 1-23.

2015: Embodied L2 construction learning. - Language Learning 65 s. 268-297.

- 2018: From trouble in the talk to new resources. The interplay of bodily and linguistic resources in the talk of a speaker of English as a second language. - Simona Pekarek Doelher, Johannes Wagner \& Esther González-Martínez (toim.), Longitudinal studies on the organization of social interaction s. 105-142. London: Palgrave Macmillan.

Evans, BRYN \& REYNOLDS, EdWARD 2016: The organization of corrective demonstrations using embodied action in sports coaching feedback. - Symbolic Interaction 39 s. 525-556. https://doi.org/10.1002/symb.255.

Firth, Alan - Wagner, Johannes 1997: On discourse, communication, and (some) fundamental concepts in SLA research. - Modern Language Journal 81 s. 285-300.

Goodwin, ChARLES 2007a: Environmentally coupled gestures. - Justine Cassell, Elena Terry Levy, David McNeill \& Susan D. Duncan (toim.), Gesture and the dynamic dimension of language. Essays in honor of David McNeill s. 195-212. Amsterdam: John Benjamins.

_ 2007b: Participation, stance and affect in the organization of activities. - Discourse \& Society 18 s. 53-73.

Hall, Joan Kelly - Hellermann, John - Pekarek Doelher, Simona (toim.) 2011: L2 Interactional competence and development. Bristol: Multilingual Matters.

Hall, Joan Kelly - Pekarek Doelher, Simona 2011: L2 interactional competence and development. - Joan Kelly Hall, John Hellermann \& Simona Pekarek Doelher (toim.), L2 interactional competence and development s. 1-15. Bristol: Multilingual Matters.

Harjunpä̈̈, Katariina - Mondada, Lorenza - Svinhufvud, Kimmo 2020: Multimodaalinen litterointi keskustelunanalyysissa. - Puhe ja kieli 39 s. 195-220. https://doi. org/10.23997/pk.77350.

Heinonen, Pilvi 2017: Evaluointi opettajan vuorovaikutustoimintana. Osallistujuuden ulottuvuudet luokkahuoneessa. Helsinki: Helsingin yliopisto. http://urn.fi/ URN:ISBN:978-951-51-3724-1.

Heller, Vivien 2016: Meanings at hand. Coordinating semiotic resources in explaining mathematical terms in classroom discourse. - Classroom Discourse 7 s. 253-275.

HeLle RMANN, JOHN 2018: Languaging as competencing. Considering language learning as enactment. - Classroom Discourse 9 s. 40-56. https://doi.org/10.1080/19463014.2018.1433052.

HellermanN, John - Harris, Kathryn 2015: Navigating the language-learning classroom without previous schooling. - Dale A. Koike \& Carl S. Blyth (toim.), Dialogue in multilingual, multimodal and multicompetent communities of practice s. 49-77. Amsterdam: John Benjamins.

Intke-Hernández, Minna - Holm, Gunilla 2015: Migrant stay-at-home mothers learning to eat and live the Finnish way. - Nordic Journal of Migration Research 5 s. 75-82. https://doi.org/10.1515/njmr-2015-0o12.

ISK = Hakulinen, Auli - Vilkuna, Maria - Korhonen, Rittta - Koivisto, Vesa - Heinonen, Tarja Rittta - Alho, Irja 2004: Iso suomen kielioppi. Helsinki: Suomalaisen Kirjallisuuden Seura.

KeEVALLIK, LEELO 2013: The interdependence of bodily demonstrations and clausal syntax. - Research on Language and Social Interaction 46 s. 1-21. https://doi.org/10.1080/08351813. 2013.753710 . 
- 2014: Turn organization and bodily-vocal demonstrations. - Journal of Pragmatics 65 s. 103-120. https://doi.org/10.1016/j.pragma.2014.01.008.

Kendon, AdAm 2004: Gesture. Visible action as utterance. New York: Cambridge University Press.

KerAVUORI, Kyllik KI 1988: Ymmärränkö tarkoitukses. Tutkimus diskurssirooleista ja funktioista. Helsinki: Suomalaisen Kirjallisuuden Seura.

Koivisto, Aino 2015: Displaying now-understanding. The Finnish change-of-stake token $a a$ - Discourse Processes 52 s. 111-148. https://doi.org/10.1080/0163853X.2014.914357.

Koivisto, Vesa 2013: Suomen sanojen rakenne. Helsinki: Suomalainen Kirjallisuuden Seura.

Koole, Tom 2010: Display of epistemic access. Student responses to teacher explanations.

- Research on Learning and Social Interaction 43 s. 183-209.

Kotilainen, Lari - Kurhila, Salla - Kalliokoski, Jyrki (toim.) 2019: Kielenoppiminen luokan ulkopuolella. Tietolipas 262. Helsinki: Suomalaisen Kirjallisuuden Seura.

Kotoklubi Kaneli. Elokuu 2019. Tiedote Helsingin kaupungin verkkosivuston Kasvatus ja koulutus -osiossa. https://www.hel.fi/helsinki/fi/kasvatus-ja-koulutus/leikki-ja-avointoiminta/perheiden-aamupaivatoiminta/suomea-toiminnallisesti-ryhmissa (27.8.2019).

Kurhila, Salla - Kotilainen, Lari 2017: Cooking, interaction and learning. The Finnish digital kitchen as a language learning environment. - Paul Seedhouse (toim.), Task-based language learning in a real-world digital environment s. 157-179. London: Bloomsbury Academic.

KÄÄNTÄ, LEILA 2010: Teacher turn-allocation and repair practices in classroom interaction. A multisemiotic perspective. Jyväskylä studies in humanities 137. Jyväskylä: University of Jyväskylä. http://urn.fi/URN:ISBN:978-951-39-3811-6.

— 2016: Määrittelemisen haasteista vieraskielisessä opetuksessa. - Soile Loukusa, Terhi Hautala, Leila Kääntä \& Anne Suvanto (toim.), Näkökulmia vuorovaikutukseen s. 42-54. Puheen ja kielen tutkimuksen yhdistyksen julkaisuja 48. Helsinki: Puheen ja kielen tutkimuksen yhdistys ry.

Kä̈̈ntä, Leila - Haddington, Pentti 2011: Johdanto multimodaaliseen vuorovaikutukseen. - Pentti Haddington \& Leila Kääntä (toim.), Kieli, keho ja vuorovaikutus. Multimodaalinen näkökulma sosiaaliseen toimintaan s. 11-45. Helsinki: Suomalaisen Kirjallisuuden Seura.

KäÄntä, Leila - Kasper, Gabriele - Piirainen-Marsh, Arja 2018: Explaining Hooke's law. Definitional practices in a CLIL physics classroom. - Applied Linguistics $39 \mathrm{~s}$. 694-717. doi: 10.1093/applin/amwo25.

LAZARATON, ANNE 2004: Gesture and speech in the vocabulary explanations of one ESL teacher. A microanalytic inquiry. - Language Learning 54 s. 79-117.

Lehtimaja, Inkeri 2012: Puheen suuntia luokkahuoneessa. Oppilaat osallistuja yläkoulun suomi toisena kielenä -tunnilla. Helsinki: Helsingin yliopisto. http://urn.fi/ URN:ISBN:978-952-10-7583-4.

Lilja, Niina - LaAkkonen, Riku - Sariola, Laura - Tapaninen, Terhi 2020: Kokemuksen keholliset esitykset. Sosiaalisen sirkuksen vuorovaikutus kielen käyttöä ja oppimista tukemassa. - Heli Paulasto \& Sari Pöyhönen (toim.), Kieli ja taide. Soveltavan kielentutkimuksen ja taiteen risteämiä. Language and the arts. Creative inquiry in applied linguistics. AFinLa-e. Soveltavan kielitieteen tutkimuksia 74 s. 32-56.

Lilja, Niina - Piirainen-Marsh, Arja 2019: Connecting the language classroom and the wild. Reenactments of language use experiences. - Applied Linguistics 40 s. 594-623. https://doi.org/10.1093/applin/amxo45. 
LINDWALl, OSKAR - EKSTRÖM, ANNA 2012: Instruction-in-interaction. The teaching and learning of a manual skill. - Human Studies 35 s. 27-49.

Majlesi, Ali Reza 2015: Matching gestures. Teachers' repetitions of students' gestures in second language learning classrooms - Journal of Pragmatics 76 s. 30-45. https://doi. org/10.1016/j.pragma.2014.11.006.

Markee, Numa - Kasper, Gabriele 2004: The classroom talks. An introduction. - Modern Language Journal 88 s. 491-50o. https://doi.org/10.1111/j.0026-7902.2004.to1-14-.X.

MCNeILl, DAVID 1992: Hand and mind. What gestures reveal about thought. Chicago: University of Chicago Press.

Menan, Hugh 1979: Learning lessons. Social organization in the classroom. Cambridge, MA: Harvard University Press.

Merke, SAIJA 2016: Establishing the explainable in Finnish-as-a-foreign-language classroom interaction. Student-initiated explanation sequences. - Learning, Culture and Social Interaction 9 s. $1-15$.

Mollanen, Kari 2002: Yli esteiden. Oppimisvaikeudet ja vieraat kielet. Helsinki: Tammi.

MONDADA, LORENZA 2014a: The local constitution of multimodal resources for social interaction. - Journal of Pragmatics 65 s. 137-156. https://doi.org/10.1016/j.pragma.2014.04.004.

- 2014b: Bodies in action. Multimodal analysis of walking and talking. - Language and Dialogue 4 s. $357-403$.

- 2016: Challenges of multimodality. Language and the body in social interaction. - Journal of Sociolinguistics 20 s. 338-366. https://doi.org/10.1111/josl.1_12177.

2018: Multiple temporalities of language and body in interaction. Challenges for transcribing multimodality. - Research on Language and Social Interaction 51 s. 85-106.

- 2020: Conventions for multimodal transcription. https://www.lorenzamondada.net/multimodal-transcription. (13.5.2020).

MORTENSEN, KRISTIAN 2008: Instructions and participation in the second language classroom. University of Southern Denmark, Institute of language and communication.

_ 2011: Doing word explanation in interaction. - Gabriele Pallotti \& Johannes Wagner (toim.), L2 learning as social practice. Conversation-analytic perspectives s. 135-162. Honolulu: University of Hawai'i, National Foreign Language Resource Center.

Morton, TOM 2015: Vocabulary explanations in CLIL classrooms. A conversation analysis perspective. - The Language Learning Journal 43 s. 256-27o. https://doi.org/10.1080/o9571 736.2015.1053283.

Mutta, Maarit - Peltonen, Paulinna - Lefebvre, Augustin - Nyikos, Julia - Hackl, Veronika - VArhegyi, Veronika 2019: Kielen ja luku- ja kirjoitustaidon opetus taiteen avulla. Metodologinen ja teoreettinen viitekehys sekä opetusmenetelmä. Language and Literacy Learning through Art. http://www.lali-project.eu/wp-content/uploads/2018/10/LALI_fi_Metodologinen-ja-teoreettinen-viitekehys_FINAL.pdf. (27.8.2019).

Möttönen, Tapani - Ahlholm, Maria 2018: The Toisto method. Speech and repetitions as a means of implicit grammar learning. - SKY Journal of Linguistics 31 s. 71-105.

Nevile, Maurice - Haddington, Pentti - Heinemann, Trine - Rauniomaa, Mirka 2014: On the interactional ecology of objects. - Maurice Nevile, Pentti Haddington, Trine Heinemann \& Mirka Rauniomaa (toim.), Interacting with objects. Language, materiality, and social activity s. 3-26. Amsterdam: John Benjamins.

Nishizaka, Aug 2017: The perceived body and embodied vision in interaction. - Mind, Culture and Activity 24 s. 110-128. https://doi.org/10.1080/10749039.2017.1296465. 
Opetus- ja kulttuuriministeriö 2017: Vapaan sivistystyön uusi sivistystehtävä. Helsinki: Opetus- ja kulttuuriministeriön julkaisuja 2017:33. http://julkaisut.valtioneuvosto.fi/bitstream/ handle/10024/80311/okm33.pdf.

Pekarek Doelher, Simona 2010. Conceptual changes and methodological challenges. On language and learning from a conversation analytic perspective on SLA. - Paul Seedhouse, Steve Walsh \& Chris Jenks (toim.), Conceptualising 'learning' in applied linguistics s. 105-126. Newcastle University, UK: Palgrave Macmillan.

RÅMAN, JoONAS 2018: The organization of transitions between observing and teaching in the budo class. - Forum Qualitative Sozialforschung / Forum Qualitative Social Research 19(1) s. 1-28. http://dx.doi.org/10.17169/fqs-19.1.2657.

RÅman, Joonas - Haddington, PentTi 2018: Demonstrations in sports training. Communicating a technique through parsing and the return-practice in the budo class. - Multimodal Communication 7(2) s. 1-19. https://doi.org/10.1515/mc-2018-ooo1.

SACKS, HARVEY 1992: Lectures on conversation. Volume 2. Toim. Gail Jefferson. Oxford: Blackwell.

SAHLSTRÖM, Fritjof 1999: Up the hill backwards. On interactional constraints and affordances for equity-constitution in the classrooms of the Swedish comprehensive school. Uppsala Studies in Education 85. Uppsala: University of Uppsala.

SChegloff, Emanuel 2007: Sequence organization in interaction. Cambridge: Cambridge University Press.

SEEDHOUSE, PAUL 2004: The interactional architecture of the language classroom. A conversation analysis perspective. Malden, MA: Blackwell.

Sert, OlCAY 2015: Social interaction and L2 Classroom Discourse. Edinburgh: University Press, Studies in Social Interaction.

- 2017: Creating opportunities for L2 learning in prediction activity. - System 70 s. 14-25.

Sinclair, John - CoulthaRD, MALCOLM 1975: Towards an analysis of discourse. The English used by teachers and pupils. London: Oxford University Press.

Stivers, Tanya - Mondada, Lorenza - Steensig, Jakob 2011: Knowledge, morality and affiliation in social interaction. - Tanya Stivers, Lorenza Mondada \& Jakob Steensig (toim.), The morality of knowledge in conversation s. 3-24. Cambridge: Cambridge University Press.

Streeck, Jürgen - Goodwin, Charles - LeBaron, Curtis 2011: Embodied interaction in the material world. An introduction. - Jürgen Streeck, Charles Goodwin \& Curtis LeBaron (toim.), Embodied interaction. Language and body in the material world s. 1-26. New York: Cambridge University Press.

Suni, Minna - Tammelin-Laine, Taina - Vertainen, Mari (toim.) 2018: Muunkieliset Euroopassa. Koulutusta aikuisille maahanmuuttajille ja heidän opettajilleen. Yhteenveto opintojaksoista. EU-Speak 3. Newcastle upon Tyne: Newcastle University.

TAI, KEVIN W. H. 2018: Vocabulary explanations and second language development in adult beginning-level ESOL classroom interaction. A conversation analysis perspective. MSc in Applied Linguistics and Second Language Acquisition. Oxford: University of Oxford.

TAI, KeVIn W. H. - BRANDT, AdAM 2018: Creating an imaginary context. Teacher's use of embodied enactments in addressing learner initiatives in a beginner-level adult ESOL classroom. - Classroom Discourse 9(3) s. 1-23.

TaI, Kevin W. H. - Khabbazbashi, Nahal 2019a: The mediation and organisation of gestures in vocabulary instructions. A microgenetic analysis of interactions in a beginning-level adult ESOL classroom. - Language and Education 33 s. 445-468. https:// 
doi.org/10.1080/09500782.2019.1596122.

2019b: Vocabulary explanations in beginning-level adult ESOL classroom interactions. A conversation analysis perspective. - Linguistics and Education 52 s. 61-77.

TAINIO, LiISA 2007: Miten tutkia luokkahuoneen vuorovaikutusta keskustelunanalyysin keinoin? - Liisa Tainio (toim.), Vuorovaikutusta luokkahuoneessa. Näkökulmana keskustelunanalyysi s. 15-58. Helsinki: Gaudeamus.

TALK = TALK - taidetta ja liikettä kieltenopetukseen. Zodiak-tanssikoulun verkkosivusto. https://www.zodiak.fi/talk/talk-hanke (27.8.2019).

TAMMELIN-LAINE, TAINA 2014a: Aletaan alusta. Luku- ja kirjoitustaidottomat aikuiset uutta kieltä oppimassa. Jyväskylä Studies in Humanities 240. Jyväskylä: Jyväskylän yliopisto. http://urn.fi/URN:ISBN:978-951-39-5997-5.

_ 2014b. Orastavan kirjoitustaidon kehitys, arviointi ja arvioinnin haasteet. - Maarit Mutta, Pekka Lintunen, Ilmari Ivaska \& Pauliina Peltonen (toim.), Tulevaisuuden kielenkäyttäjä. Language users of tomorrow s. 49-69. AFinLAn vuosikirja 2014. Suomen soveltavan kielitieteen yhdistyksen julkaisuja 72. Jyväskylä: Suomen soveltavan kielitieteen yhdistys AFinLA ry.

Tarone, Elaine - Bigelow, Martha - Hansen, Kit 2009: Literacy and second language oracy. Oxford: Oxford University Press.

TAŞKIN, ELIF 2017: Interactional unfolding of vocabulary explanations in meaning and fluency context. - International Online Journal of Education and Teaching (IOJET) 4 s. 562-575. http://iojet.org/index.php/IOJET/article/view/244/191.

Testipiste 2016 = Sandberg, Tanja - Stordell, Elina 2016: Vastaanottokeskuksissa toteutettu alkuvaiheen osaamisen tunnistaminen. https://minedu.fi/documents/1410845/4240776/ VOK-raportti_2016/86eao123-d929-4aa6-b453-95eaa1ec2dd7/VOK-raportti_2016.pdf.

Waring, Hansun Zhang - Creider, Sarah Chepkirui - Box, Catheriene DifELICE 2013: Explaining vocabulary in the second language classroom. A conversation analytic account. - Learning, Culture and Social Interaction 2 s. 249-264. https://doi. org/10.1016/j.lcsi.2013.08.001.

Zhao, Ting - Macaro, Ernesto 2016: What works better for the learning of concrete and abstract words: teachers' L1 use or L2-only explanations? - International Journal of Applied Linguistics 26 s. 75-98. https://doi.org/10.1111/ijal.1208o.

\title{
Liite
}

\section{Puheen litterointimerkit}

\author{
Sävelkulku \\ Prosodisen kokonaisuuden lopussa: \\ laskeva intonaatio \\ tasainen intonaatio \\ ? nouseva intonaatio \\ Prosodisen kokonaisuuden sisällä tai alussa: \\ $\uparrow \quad$ seuraava sana lausuttu ympäristöä korkeammalta \\ $\downarrow \quad$ seuraava sana lausuttu ympäristöä matalammalta \\ avata (alleviivaus) painotus
}




\section{Päällekkäisyydet ja tauot}

[ päällekkäispuhunnan alku

] päällekkäispuhunnan loppu

(.) mikrotauko: 0.2 sekuntia tai vähemmän

(o.4) mikrotaukoa pidempi tauko; pituus ilmoitettu sekunnin kymmenesosina

$=\quad$ kaksi puhunnosta liittyy toisiinsa tauotta

\section{Puhenopeus ja äänen voimakkuus}

$>$ kyllä< (sisäänpäin osoittavat nuolet) nopeutettu jakso

$<$ kyllä> (ulospäin osoittavat nuolet) hidastettu jakso

vesi: (kaksoispisteet) äänteen venytys

${ }^{\circ}$ vesi- ${ }^{\circ} \quad$ (astemerkit) ympäristöä vaimeampaa puhetta

JOO (kapiteelit) äänen voimistuminen

\section{Hengitys}

.hhh sisäänhengitys; yksi h-kirjain on o.1 sekuntia

hhh uloshengitys

.joo (piste sanan edessä) sana lausuttu sisäänhengittäen

\section{Nauru}

he he naurua

j(h)oo suluissa oleva h sanan sisällä kuvaa uloshengitystä; useimmiten kyse nauraen lausutusta sanasta

$€ j o o € \quad$ hymyillen sanottu sana tai jakso

\section{Muuta}

\#joo\# nariseva ääni

@joo@äänen laadun muutos

jo- (tavuviiva) sana jää kesken

(joo) sulkujen sisällä selvästi kuultu tai puhuja

(-) sana, josta ei ole saatu selvää

(--) pidempi jakso, josta ei ole saatu selvää

(( ) ) kaksoissulkeiden sisällä litteroijan kommentteja ja selityksiä tilanteesta

Muun multimodaalisen toiminnan litterointimerkit

$\begin{array}{ll}+ & \text { OPE:n katse } \\ \Pi & \text { YAFin katse } \\ \text { d } & \text { MO1:n katse } \\ \square & \text { KARin katse } \\ \wedge & \text { IB1:n katse } \\ \# & \text { AKR:n katse } \\ \cap & \text { ISM:n katse } \\ * & \text { OPE:n kehollinen toiminta }\end{array}$


o ISM:n kehollinen toiminta

$\triangle \quad$ KAR:n kehollinen toiminta

$\varnothing \quad$ IB1:n kehollinen toiminta

$\Sigma \quad$ YAF:n kehollinen toiminta

\$ SAL:n kehollinen toiminta

Q AKR:n kehollinen toiminta
Lyhenteet
OK oikea käsi
VK vasen käsi 


\section{Embodied and material word explanations in adult literacy-training classroom interactions}

In this article, multimodal conversation analysis is employed to analyse classroom interaction between users of Finnish as a second language. More specifically, the author investigates the structure of co-constructed multimodal word explanation sequences that occurred after a dictation exercise during a classroom interaction given as part of adult literacy training. Typically, the salient word is repeated, there then follows a co-constructed multimodal word explanation, after which the conversation focuses on the semiotics of the word in question. Finally, students repeat the word again. To explain words, students primarily use embodied resources, most often iconic gestures or embodied enactments. For instance, a student might demonstrate the action of drinking to explain what the word vesipullo ('water bottle') refers to, or physically enact opening a door when the teacher has asked what avata ('to open') means. The analysis discusses how comprehension is demonstrated in embodied turns in which the participants' shared linguistic resources are limited.

The longitudinal data was collected ethnographically over eight months, both from classroom interactions and everyday encounters with groups of adult second-language and literacy learners in Finland. The data for the article comprises approximately 68 hours of video and audio recordings.

The empirical findings of this study present new information about the structure of word-explanation sequences and the role of embodied and material resources used therein. Moreover, they shed light on questions of the role of multimodal resources in second-language and literacy training and call for further research into the development of their use over time. 


\section{Keholliset ja materiaaliset sananselityssekvenssit aikuisten S2-lukutaito-opiskelijoiden luokkahuonevuorovaikutuksessa}

Tässä artikkelissa analysoidaan multimodaalista keskustelunanalyysia hyödyntäen, miten sanelun jälkeiset sekvenssit rakentuvat aikuisten luku- ja kirjoitustaidon koulutuksen luokkahuoneen vuorovaikutuksessa. Pitkittäinen aineisto on kerätty etnografisesti aikuisten luku- ja kirjoitustaidon koulutuksen yhteydestä sekä luokkahuoneen että arjen vuorovaikutustilanteista kahdeksan kuukauden aikana. Artikkelin aineisto sisältää 68 tuntia videotallenteita.

Artikkelissa osoitetaan, että tyypillisesti huomion kohteeksi tuotu sana aluksi toistetaan, mitä seuraa yhdessä rakennettu multimodaalinen sananselitys. Tämän jälkeen fokusoidaan sanan semantiikkaan ja lopuksi sana taas toistetaan. Sananselitykset koostuvat yleensä ikonisista eleistä tai kehollisista esityksistä. Opiskelija saattaa esimerkiksi demonstroida juomistoimintaa selittääkseen, mihin vesipullo viittaa tai kehollisesti esittää avaavansa oven opettajan kysyttyä, mitä avata-sana tarkoittaa. Näin ollen analyysissa pohditaan, miten ymmärtämistä voidaan osoittaa kehollisilla vuoroilla, kun osallistujien yhteiset kielelliset resurssit ovat vähäiset.

Artikkeli tuo uutta tietoa luku- ja kirjoitustaidon koulutuksen sananselitysten rakenteesta ja kehollisten ja materiaalisten resurssien merkityksestä niissä. Lisäksi esitetty analyysi nostaa esiin tarpeen tutkia, miten lukutaito-opiskelijoiden multimodaalisten resurssien käyttö mahdollisesti muuttuu ja kehittyy ajan kuluessa.

Kirjoittajan yhteystiedot:

etunimi.sukunimi@tuni.fi

Kirjoittaja on väitöskirjatutkija Tampereen yliopistossa. 